\title{
TINGKAT KETAHANAN PANGAN PADA RUMAHTANGGA YANG DIKEPALAI PRIA DAN RUMAHTANGGA YANG DIKEPALAI WANITA
}

\author{
Food Security Level of Male Headed Households and Female Households \\ Tri Yulyanti Fathonah*) dan Nuraini W. Prasodjo \\ Departemen Sains Komunikasi dan Pengembangan Masyarakat, Fakultas Ekologi Manusia, IPB \\ *) E-mail : 3yuliyanti_f@gmail.com
}

Diterima 24 Januari 2011/Disetujui 5 April 2011

\begin{abstract}
The purpose of this research was to determine the level of food security in both types of households, namely male headed households (RTKP) and female headed households (RTKW). The objective of this research are male headed households (RTKP) and female headed households (RTKW) ) in Jembatan Serong Community. The research methode uses a quantitative approach to survai research that is supported by qualitative data. The respondents were selected by applying simple random sampling technique. The results of this study showed that households in Jembatan Serong Community belong to the category of food security and food security inequality do not occur in RTKP and RTKW. Based on cross tabulation, the education of food administrators of RTKP and RTKW associated with the level of food security and income levels RTKP and RTKW associated with the level of food security.
\end{abstract}

Keywords: food security level, male headed households, female headed households.

\section{PENDAHULUAN}

\section{Latar Belakang}

Pangan merupakan hal penting yang harus dipenuhi oleh setiap manusia untuk keberlangsungan hidupnya. Pangan yang dimaksud dalam hal ini adalah pangan pokok bagi masyarakat Indonesia, yaitu beras, sumber karbohidrat bagi tubuh. Tercukupinya asupan gizi yang terkandung dalam pangan dan diserap oleh tubuh dapat menghasilkan sumber daya manusia yang berkualitas. Mengingat pentingnya memenuhi kecukupan pangan, maka setiap negara akan mendahulukan pembangunan ketahanan pangannya sebagai fondasi bagi pembangunan sektor-sektor lainnya (Arumsari dan Rini, 2007). Oleh karena itu, Indonesia berkomitmen untuk mewujudkan ketahanan pangan dan hal tersebut dituangkan dalam Undang-Undang Nomor 7 tahun 1996 tentang pangan. Undang-Undang tersebut mendefinisikan ketahanan pangan sebagai suatu kondisi terpenuhinya pangan bagi rumah tangga yang tercermin dari tersedianya pangan yang cukup dalam jumlah maupun mutunya, aman, merata, dan terjangkau. Berdasarkan definisi tersebut, ketahanan pangan yang dimaksud tidak hanya di tingkat global, nasional, dan regional tapi juga sampai pada tingkat rumah tangga.

Ketersediaan pangan nasional dan regional tidak menjamin adanya ketahanan pangan rumahtangga atau individu karena ketersediaan pangan dan ketahanan pangan ditentukan oleh akses untuk mendapatkan pangan (Saliem et al., 2005). Dampak dari ketiadaan akses terhadap pangan salah satunya seperti yang terjadi di Indonesia, yaitu krisis pangan di Yahukimo, Papua yang mengakibatkan terjadinya kasus kelaparan besarbesaran.

Perlu dipahami terlebih dahulu mengenai konsep rumahtangga dalam kaitannya dengan ketahanan pangan di tingkat rumahtangga. Konsep rumahtangga yang dimaksud adalah seorang atau sekelompok orang yang mendiami sebagian atau seluruh bangunan fisik atau sensus dan biasanya tinggal bersama serta makan dari satu dapur ${ }^{1}$. Secara umum, rumahtangga di Indonesia ada dua tipe, yaitu rumahtangga yang dikepalai oleh pria (RTKP) dan rumahtangga yang dikepalai oleh wanita (RTKW). Pria dan wanita yang menjadi kepala rumahtangga ini merupakan orang yang berkontribusi ekonomi terbesar dalam rumahtangga dan juga sebagai pencari nafkah utama. Jika ditinjau berdasarkan tipe rumahtangga, diduga akan terjadi ketimpangan ketahanan pangan dimana ketahanan pangan RTKP lebih tahan pangan dibandingkan dengan RTKW. Dugaan tersebut diperkuat berdasarkan hasil penelitian yang dilakukan oleh Pusat Studi Wanita-Institut Pertanian Bogor (1998), yang menyatakan bahwa

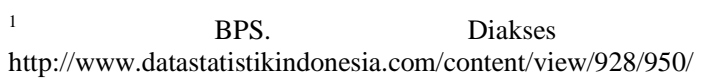$$
\text { pada tanggal } 14 \text { April } 2010 .
$$

dari 
rumahtangga-rumahtangga yang dikepalai oleh wanita seringkali termasuk ke dalam rumahtangga paling miskin yang disebabkan oleh diskriminasi dalam pengupahan, pola pembagian kerja pada pasar tenaga kerja, serta kendala-kendala lainnya yang berkaitan dengan gender. Ketimpangan tersebut pada akhirnya akan berdampak pada kualitas sumberdaya manusia. Besarnya pendapatan yang diperoleh oleh RTKP dan RTKW dipengaruhi oleh jenis pekerjaan yang dilakukannya. Pada masyarakat transisi, yaitu masyarakat yang sedang mengalami perubahan dari masyarakat pertanian ke masyarakat industri, jumlah pendapatan yang diterima oleh wanita yang bekerja di sektor industri berbeda dengan jumlah pendapatan yang diterima oleh pria walaupun pekerjaan yang dilakukan oleh keduanya sama. Kesenjangan tingkat upah antara pekerja wanita dengan pekerja pria seperti dalam Laporan Country Gender Assessment 2006 mengenai Indonesia, menunjukkan bahwa rata-rata upah yang diterima oleh pekerja wanita per jam hanya 70 persen daripada pendapatan yang diterima oleh pekerja pria (Susiana, 2009). Perbedaan tingkat pendapatan RTKP dan RTKW yang tergolong masyarakat transisi diperkirakan berhubungan dengan kemampuannya dalam mengakses atau memenuhi kebutuhan pangannya. Oleh karena itu, diduga bahwa tingkat pendapatan RTKP dan RTKW berhubungan dengan tingkat ketahanan pangan. Selain perbedaan tingkat pendapatan, diduga tingkat pendidikan pengelola pangan RTKP dan RTKW berhubungan dengan tingkat ketahanan pangan rumahtangga. Pengelola pangan baik pada RTKP maupun RTKW merupakan orang yang memutuskan untuk memilih jenis pangan yang akan dikonsumsi dan jumlah pengeluaran pangan yang akan dibeli. Penelitian ini mengkaji mengenai ketahanan pangan di kedua tipe rumahtangga, yaitu RTKP dan RTKW. Penelitian-penelitian sebelumnya mengenai ketahanan pangan belum ada yang membahas ketahanan pangan pada tipe rumahtangga sehingga penelitian tersebut menarik untuk ditelaah lebih lanjut.

\section{Perumusan Masalah}

Berdasarkan latar belakang yang telah diuraikan, maka perumusan masalah penelitian ini adalah:

1. Bagaimanakah tingkat ketahanan pangan pada masing-masing tipe rumahtangga, yaitu rumahtangga yang dikepalai pria (RTKP) dan rumahtangga yang dikepalai wanita (RTKW)?

2. Sejauh manakah ketimpangan ketahanan pangan yang terjadi diantara kedua tipe rumahtangga tersebut?

3. Bagaimanakah hubungan tingkat pendidikan pengelola pangan dan tingkat pendapatan rumahtangga dengan tingkat ketahanan pangan pada rumahtangga yang dikepalai pria (RTKP) dan rumahtangga yang dikepalai wanita (RTKW)?

\section{Tujuan Penelitian}

Berdasarkan latar belakang yang telah diuraikan, maka tujuan dari penelitian ini, yaitu untuk:
1. Mengetahui tingkat ketahanan pangan pada masingmasing tipe rumahtangga, yaitu rumahtangga yang dikepalai pria (RTKP) dan rumahtangga yang dikepalai wanita (RTKW).

2. Mengetahui sejauh mana ketimpangan ketahanan pangan yang terjadi diantara kedua tipe rumahtangga tersebut.

3. Mengetahui hubungan tingkat pendidikan pengelola pangan dan tingkat pendapatan rumahtangga dengan tingkat ketahanan pangan pada rumahtangga yang dikepalai pria (RTKP) dan rumahtangga yang dikepalai wanita (RTKW).

\section{PENDEKATAN TEORITIS}

\section{Tinjauan Pustaka}

\section{Konsep Ketahanan Pangan}

Ketahanan pangan merupakan komitmen Indonesia pada sektor pembangunan pangan. Komitmen tersebut dituangkan dalam beberapa kebijakan, yaitu dalam Undang-Undang Nomor 7 tahun 1996 tentang pangan dan Peraturan Pemerintah RI Nomor 68 tahun 2002 tentang ketahanan pangan. Menurut Undang-Undang Nomor 7 tahun 1996 dan Peraturan Pemerintah RI Nomor 68 tahun 2002 tentang pangan, ketahanan pangan didefinisikan sebagai suatu kondisi terpenuhinya pangan bagi rumahtangga yang tercermin dari tersedianya pangan yang cukup dalam jumlah maupun mutunya, aman, merata, dan terjangkau (Rahayu, 2007). Terdapat beberapa definisi lain tentang ketahanan pangan yang dikemukakan baik oleh lembaga perbankan maupun hasil konferensi internasional. Menurut World Bank dalam Indaryanti (2003) mendefinisikan ketahanan pangan sebagai akses semua orang pada setiap saat terhadap pangan yang mencukupi untuk menjamin kehidupan yang aktif dan sehat. Berdasarkan hasil konferensi internasional World Conference on Human Right (1993) dalam Saliem (2005), ketahanan pangan didefinisikan sebagai kondisi terpenuhinya kebutuhan gizi setiap individu baik dalam jumlah maupun mutu agar dapat hidup aktif dan sehat secara berkesinambungan sesuai dengan budaya setempat. Salah satu definisi ketahanan pangan yang dituangkan dalam kebijakan UU RI No. 7 tahun 1996 sesuai dengan yang dikemukakan oleh Chung (1997) dalam Maisaroh (2001), bahwa ketahanan pangan mempunyai tiga komponen utama, yaitu:

\section{a. Ketersediaan Pangan}

Menurut Braun et al. (1992) dalam Antang (2002), pada tingkat rumahtangga, ketersediaan pangan dapat dipenuhi dari produksi pangan sendiri dan membeli pangan yang tersedia di pasar.

b. Akses Pangan

Akses pangan terkait dengan akses ekonomi bagi individu untuk memperoleh pangan. Akses pangan terjamin apabila rumahtangga dan individu di dalamnya memiliki sumberdaya yang cukup untuk mendapatkan pangan yang tepat untuk konsumsi yang bergizi dan akses pangan ini tergantung pada pendapatan rumahtangga, distribusi pendapatan di 
dalam rumahtangga dan harga pangan (WFP, 1998; Riely et al., 1999 dalam Rahayu, 2007).

\section{c. Pemanfaatan Pangan}

Pemanfaatan pangan adalah penggunaan sifat biologi yang dimiliki pangan, kebutuhan akan konsumsi yang memberikan energi dan zat gizi essensial, air yang sehat, dan sanitasi yang baik (WFP, 1998; Riely et al., 1999 dalam Rahayu, 2007). Pemanfataan pangan dapat diartikan sebagai konsumsi pangan.

Perwujudan sistem ketahanan pangan di tingkat rumahtangga (mikro) dalam kerangka hubungannya dengan sistem ketahanan pangan di tingkat wilayah atau negara (makro) digambarkan pada Gambar 1. Tercapainya ketahanan pangan di tingkat makro belum tentu tercapai pula ketahanan pangan di tingkat mikro. Hal tersebut disebabkan oleh adanya pengaruh individu dan rumahtangga. Jika ditinjau dari sistem kelembagaan sosial pangan masyarakat, terwujudnya ketahanan pangan merupakan hasil dari bekerjanya secara sinergis suatu sistem yang terdiri dari subsistem rumahtangga, subsistem lingkungan masyarakat, dan subsistem pemerintah. Subsistem rumahtangga mengelola penyediaan, cadangan, dan pola konsumsi yang menjamin setiap individu memperoleh asupan gizi yang cukup. Subsistem lingkungan masyarakat mengatur penyelenggaraan produksi, distribusi, dan pemasaran yang menjamin penyediaan pangan di seluruh wilayah setiap saat. Adapun subsistem pemerintah mengelola kebijakan, fasilitas, pelayanan, dan pengawasan yang menjamin sistem usaha pangan secara adil dan bertanggung jawab (Rindayati, 2009).

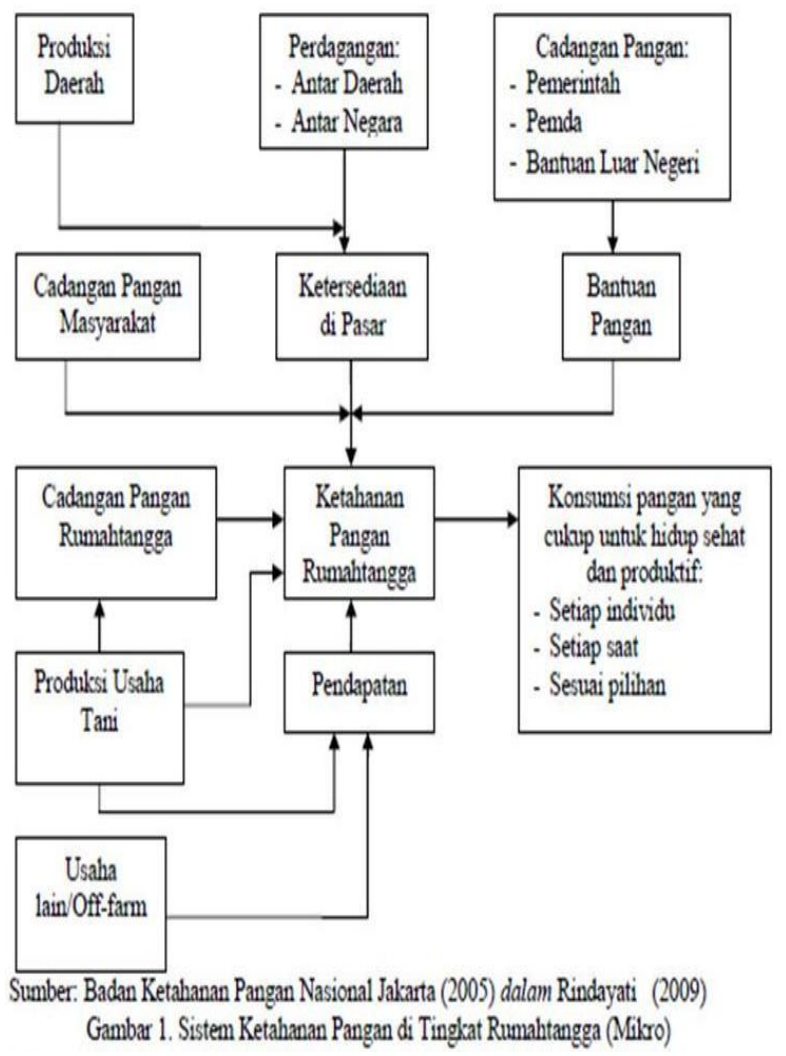

\section{Pengukuran Ketahanan Pangan}

Ketahanan pangan dapat diukur dengan dua metode, yaitu metode kuantitatif dan metode kualitatif. Metode kuantitatif menurut Smith (2002) dan Ferro-Luzzi (2002) dalam Antang (2002), dilakukan dengan menggunakan survei pengeluaran rumahtangga atau Household Expenditure Survey (HES) dan asupan pangan individu atau Individual Food Intake (IFI). Terdapat empat variabel yang digunakan untuk mengukur ketahanan pangan dari survei pengeluaran rumahtangga seperti yang dikemukakan oleh Smith (2002) dalam Antang (2002), yaitu a) jumlah konsumsi energi rumahtangga, b) tingkat kecukupan energi, c) diversifikasi pangan, dan d) persen pengeluaran untuk pangan.

Sejak dua dekade lalu, para peneliti telah mengidentifikasi seperangkat pola kondisi, pengalaman, dan perilaku yang secara konsisten menggambarkan fenomena ketidaktahanan pangan dan kelaparan. Di Amerika Serikat telah dikembangkan pengukuran ketahanan pangan yang dilakukan dengan metode kualitatif menggunakan alat kuesioner. Pertanyaan dalam kuesioner untuk berbagai indikator ini telah tertuang dalam Current Population Survey (CPS) Food Security Supplement di Amerika Serikat pada tahun 1995, yang menjadi dasar bagi pengukuran ketahanan pangan. Menurut Bickel et al. (2000) dalam Rahayu (2007), "modul inti" CPS (bagian kunci CPS Food Security Supplement) menanyakan tentang bermacam kondisi kejadian perilaku dan reaksi subjektif berupa: (1) kekhawatiran bahwa anggaran pangan rumahtangga atau ketersediaan pangan kemungkinan tidak mencukupi; (2) persepsi bahwa konsumsi orang dewasa atau anak-anak dalam rumahtangga tidak mencukupi dari segi kualitas, (3) kejadian mengurangi konsumsi orang dewasa dalam rumahtangga, atau berbagai akibat yang muncul dari mengurangi asupan makanan dan (4) kejadian mengurangi makanan atau berbagai akibat yang muncul karena mengurangi asupan makanan pada anak-anak dalam rumahtangga. Menurut Bickel et al. (2000) dalam Rahayu (2007), pertanyaan yang tercakup dalam modul inti dikombinasikan ke dalam suatu ukuran yang disebut skala ketahanan pangan. Selanjutnya skala ketahanan pangan disederhanakan ke dalam pengkategorian yang bermakna "tingkat keparahan", antara lain:

a. tahan pangan yaitu apabila rumahtangga menunjukkan tidak ada atau hanya sedikit bukti ketidaktahanan pangan.

b. tidak tahan pangan tanpa kelaparan yaitu keadaan tidak tahan pangan terbukti pada anggota rumahtangga yang perhatian terhadap kecukupan suplai pangan rumahtangga dan menyesuaikannya dengan manajemen rumahtangga dengan cara menurunkan kualitas pangan dan meningkatkan bentuk koping yang luar biasa. Dalam hal ini hanya sedikit atau tidak ada pengurangan asupan makanan anggota rumahtangga.

c. tidak tahan pangan dengan kelaparan sedang terjadi apabila asupan makanan bagi orang dewasa dalam 
rumahtangga dikurangi sehingga mengalami pengalaman sensasi fisik berupa kelaparan yang berulang. Pada sebagian besar rumahtangga tidak tahan pangan yang memiliki anak, tindakan mengurangi asupan makanan pada anak-anak tidak terbukti.

d. tidak tahan pangan dengan kelaparan berat yaitu keadaan bagi semua rumahtangga yang memiliki anak melakukan pengurangan asupan makanan untuk anak-anak sehingga anak-anak mengalami kelaparan. Bagi beberapa rumahtangga lain yang memiliki anak, hal ini telah terjadi pada saat awal tahap keparahan yang berat. Adapun keadaan orang dewasa dalam rumahtangga yang memiliki anak maupun yang tidak memiliki anak mengalami pengalaman yang berulang dan lebih meluas dalam hal pengurangan asupan makanannya.

\section{Faktor-faktor yang Berhubungan dengan Ketahanan Pangan}

Ketahanan pangan rumahtangga dapat berhubungan dengan berbagai macam faktor, antara lain tingkat pendidikan pengelola pangan rumahtangga, tingkat pendapatan rumahtangga, dan struktur rumahtangga. Pengelola pangan di rumahtangga pada umumnya adalah ibu. Alderman \& Gracia (1994) dalam Antang (2002), menyatakan bahwa tingkat pendidikan ibu berhubungan dengan ketahanan pangan melalui konsumsi pangan rumahtangga dan pendidikan kepala rumahtangga turut mempengaruhi pula, akan tetapi tidak sebesar pengaruh akibat tingkat pendidikan ibu. Menurut Tanziha (2005), tingkat pendidikan yang tinggi juga berhubungan dengan pendapatan. Rumahtangga dengan ibu berpendidikan tinggi biasanya mempunyai lebih banyak uang yang dapat digunakan untuk pembelian pangan. Penelitian lainnya mengenai ketahanan pangan yang dilakukan oleh Khomsan menemukan bahwa indikator ketahanan pangan di Jawa adalah konsumsi beras, tempe, tahu, serta pendidikan ayah dan ibu. Khomsan juga menyatakan bahwa semakin tinggi pendidikan ayah dan ibu maka pendapatan rumahtangga juga akan semakin tinggi sehingga mereka memiliki daya beli pangan yang lebih besar (Khomsan, 1999 dalam Maisaroh, 2001).

Selain pendidikan, pendapatan juga berhubungan dengan ketahanan pangan, dimana seperti yang dinyatakan oleh Khomsan bahwa semakin tinggi pendidikan maka pendapatan akan semakin tinggi pula dan pada akhirnya daya beli pangan juga akan lebih besar. Menurut FAO (1997) dalam Tanziha (2005), bahwa determinan utama dari ketahanan pangan/ketidaktahanan pangan adalah pendapatan yang memadai atau daya beli untuk memenuhi biaya hidup. Menurut Hunger Site (2003) dalam Tanziha (2005), peningkatan pendapatan keluarga dapat memperbaiki ketahanan pangan keluarga melalui peningkatan akses mereka terhadap pangan. Menurutnya, konsumsi pangan sangat berhubungan dengan tingkat pendapatan, berdasarkan hasil penelitiannya baik di perkotaan maupun di pedesaan menunjukkan bahwa pendapatan berhubungan nyata dengan konsumsi kalori. Menurut Kamla Bhasin dan Nighat Said Khan (1995) dalam
Susiana (2009), rendahnya gaji atau upah yang diterima oleh wanita tidak terlepas dari pandangan patriarkis bahwa wanita kurang produktif jika dibandingkan dengan pria. Selanjutnya, disebutkan bahwa pria sebagai kepala rumahtangga dibayar dengan "upah keluarga", yaitu upah yang meliputi kebutuhan hidup bagi dirinya sendiri, istri, dan anak-anaknya. Sebaliknya, wanita yang melakukan kerja produktif hanyalah memberi tambahan pendapatan keluarga dan oleh karenanya dapat diberi upah yang kurang daripada pekerja pria, bahkan untuk pekerjaan yang sama nilainya. Masih menurut Kamla Bhasin dan Nighat Said Khan (1995) dalam Susiana (2009), pandangan patriarkis seperti itu sebenarnya bertentangan dengan kenyataan yang ada di lapangan. Struktur rumahtangga juga berhubungan dengan ketahanan pangan rumahtangga. Struktur rumahtangga yang dimaksud didefinisikan sebagai komposisi rumahtangga yang terdiri dari anggota rumahtangga. Jumlah anggota rumahtangga berhubungan dengan pengeluaran untuk pangan. Suhardjo (1989) dalam Tanziha (2005), mengemukakan bahwa meningkatnya jumlah anggota keluarga tanpa diimbangi dengan peningkatan pendapatan, maka pendistribusian konsumsi pangan akan semakin sedikit sehingga konsumsi pangan keluarga tersebut tidak cukup untuk mencegah kejadian kurang gizi. Tipe rumahtangga yang ada di Indonesia ada dua, yaitu rumahtangga yang dikepalai pria dan rumahtangga yang dikepalai wanita. BPS mendefinisikan wanita kepala rumahtangga adalah wanita yang belum kawin, cerai, atau janda dan tinggal sendiri atau bersama anak-anak atau anggota rumahtangga lainnya, serta mengurus rumahtangganya sendiri terpisah dari orang lain (Surbakti, 1990). Wanita yang berstatus kawin terhitung sebagai kepala rumahtangga bila suaminya tinggal di tempat lain. Menurut Surbakti (1991), secara de jure wanita digambarkan sebagai kepala rumahtangga, karena memang hidup berumahtangga sendiri, dalam arti tidak menikah atau karena bercerai, cerai-hidup atau cerai-mati. Secara de facto wanita digambarkan sebagai kepala rumahtangga karena wanita merantau tanpa suami atau sebaliknya dan berumahtangga sendiri. Pada status sosial dalam masyarakat, wanita menjadi pencari nafkah utama dan menjadi penanggung jawab untuk rumahtangga. Hal ini berlaku pula untuk rumahtangga dengan kehadiran suami tetapi suami tidak mampu secara fisik atau mental untuk mengelola rumahtangganya (Surbakti, 1991). Berdasarkan pengamatan makro terhadap lima jenis komunitas, Surbakti (1991) dalam Pusat Studi Wanita-Institut Pertanian Bogor (1998) mengemukakan bahwa: (1) Umumnya rumahtangga yang dikepalai wanita mempunyai status ekonomi yang lebih rendah dibanding rumahtangga yang dikepalai pria, (2) Ada kesenjangan status ekonomi yang nyata antara rumahtangga yang dikepalai wanita dan rumahtangga yang dikepalai pria dan kesenjangan tersebut bersumber pada susunan anggota rumahtangga pencari nafkah, pendidikan, dan kesempatan bekerja, dan (3) Status ekonomi rumahtangga yang dikepalai wanita sangat dipengaruhi oleh komunitasnya. 
Penelitian yang dilakukan oleh Grijns (1992) membagi tahapan siklus hidup wanita menjadi lima, yaitu wanita melajang, wanita menikah dan memiliki anak kecil, janda dengan anak kecil, janda dengan anak dewasa, dan janda lansia (Grijns et al., 1992). Siklus hidup yang dikemukakan oleh Grijns tersebut tidak hanya berlaku pada wanita tapi juga berlaku pada pria. Penelitian lain mengenai rumahtangga dilakukan oleh White, dimana ia membagi rumahtangga ke dalam empat tahapan ekspansi demografis, yaitu a) ekspansi awal (anak tertua 0-9 tahun), b) ekspansi pertengahan (anak tertua 10-14 tahun), c) ekspansi lanjut (anak tertua 15 tahun ke atas), dan d) ekspansi penyebaran (ada anak memisahkan diri dari rumahtangga) (White, 1976 dalam Sitorus, 1990 dalam Prasodjo, 1993). Hasil penelitian yang dilakukan oleh Surbakti (1991), Grijns (1992), dan White (1976) dikombinasikan sehingga dalam penelitian ini struktur rumahtangga terbagi ke dalam empat kategori berdasarkan siklus hidupnya, yaitu (1) rumahtangga lajang, dimana wanita atau pria lajang menjadi kepala rumahtangga (pencari nafkah) karena orangtuanya meninggal atau sudah tidak mampu mengelola rumahtangga dan memiliki tanggungan anggota rumahtangga lainnya. (2) rumahtangga tanpa anak, dimana wanita atau pria yang sudah menikah baik yang masih memiliki pasangan maupun yang sudah tidak memiliki pasangan (janda/duda) menjadi kepala rumahtangga (pencari nafkah) namun tidak memiliki anak atau tanggungan anggota rumahtangga lainnya. (3) rumahtangga tahap ekspansi demografis awal, dimana wanita atau pria yang sudah menikah baik yang masih memiliki pasangan (namun pasangannya tidak mampu secara fisik dan mental mengelola rumahtangganya) maupun yang sudah tidak memiliki pasangan (janda/duda) menjadi kepala rumahtangga (pencari nafkah) serta memiliki anak tertua berusia $<10$ tahun. (4) rumahtangga tahap ekspansi demografis lanjut, dimana wanita atau pria yang sudah menikah baik yang masih memiliki pasangan (namun pasangannya tidak mampu secara fisik dan mental mengelola rumahtangganya) maupun yang sudah tidak memiliki pasangan (janda/duda (termasuk janda/duda yang usianya $\geq 60$ tahun) ) menjadi kepala rumahtangga (pencari nafkah) serta memiliki anak tertua berusia $\geq 10$ tahun baik yang masih tinggal satu rumah maupun yang sudah menikah dan berpisah dari orangtuanya (membentuk keluarga baru). Oleh karena itu, baik tipe rumahtangga RTKW maupun RTKP terdiri dari empat struktur rumahtangga berdasarkan siklus hidupnya, yaitu rumahtangga lajang, rumahtangga tanpa anak, rumahtangga tahap ekspansi demografis awal, dan rumahtangga tahap ekspansi demografis lanjut.

\section{Penelitian Sebelumnya mengenai Ketahanan Pangan}

Penelitian yang dilakukan oleh Indaryanti (2003) dengan topik analisis strategi ketahanan pangan komunitas, menunjukkan bahwa rumahtangga petani berada pada kondisi ketahanan pangan yang cukup baik dan secara relatif berada pada keadaan "tahan pangan". Kondisi terjadinya perubahan pendapatan pada rumahtangga petani secara relatif tidak secara langsung mempengaruhi alokasi pengeluaran rumahtangga yang bersangkutan untuk bahan pangan beras. Ada dua strategi yang dilakukan untuk memenuhi ketersediaan dan konsumsi pangan, yaitu strategi pengalihan kelebihan pendapatan dan strategi penyesuaian konsumsi. Strategi pengalihan kelebihan pendapatan rumahtangga petani berbeda-beda, dilihat dari besarnya lahan yang dimilikinya. Selain mengenai strategi ketahanan pangan, ada juga peneliti yang mengkaji mengenai ketahanan pangan rumahtangga dan peranan modal sosial, seperti yang dilakukan oleh Alfiasari (2007), dimana hasil penelitiannya menunjukkan bahwa 63,3 persen rumahtangga miskin di Kelurahan Kedung Jaya dan 67,6 persen rumahtangga miskin di Kelurahan Tajur berada dalam kondisi tidak tahan pangan. Ada faktor lain yang berperan dalam menciptakan rumahtangga yang tahan pangan, selain kemampuan ekonomi rumahtangga. Potensi tersebut tidak selalu berbentuk uang namun secara ekonomi bermanfaat dalam membantu rumahtangga tetap tahan pangan meskipun kemampuan ekonominya rendah. Salah satu potensi tersebut adalah hubungan sosial atau modal sosial antar rumahtangga miskin.

Penelitian yang dilakukan oleh Elizabeth (2007) mengenai peran ganda wanita tani dalam mencapai ketahanan pangan rumahtangga di pedesaan, menunjukkan bahwa pada dasarnya, wanita memiliki peranan ganda dalam rumahtangga, yang terimplikasi dari (1) peran kerja sebagai ibu rumahtangga (feminine role), dan (2) peran sebagai pencari nafkah (tambahan atau utama). Akibat meningkatnya pendapatan yang diperoleh melalui pola nafkah ganda sebagai konsekuensi peran ganda wanita tani, maka kebutuhan pangan rumahtangga sehari-hari diharapkan dapat terpenuhi. Peningkatan produktivitas tenaga kerja wanita tani memiliki peran dan potensi yang strategis dalam mendukung peningkatan maupun perolehan pendapatan rumahtangga pertanian di pedesaan. Penelitian lainnya yang dilakukan oleh Sukiyono et al. (2008) mengenai status wanita dan ketahanan pangan rumahtangga nelayan dan petani padi, menunjukkan bahwa peranan anggota rumahtangga, termasuk wanita (istri), dalam mempertahankan pangan bagi rumahtangga, tidak terlepas dari atribut yang melekat pada anggota rumahtangga, seperti faktor umur, pendidikan, pengalaman, perilaku (intern), jumlah tanggungan rumahtangga, luas lahan garapan, orientasi produksi, dan status wanita. Faktor-faktor ini secara teoritik akan menentukkan ketahanan pangan bagi rumahtangga.

\section{Kerangka Pemikiran}

Skala ketahanan pangan dalam penelitian ini disebut dengan tingkat ketahanan pangan dan disederhanakan menjadi dua kategori, yaitu tidak tahan pangan dan tahan pangan. Dalam penelitian ini terdapat dua tipe rumahtangga, yaitu rumahtangga yang dikepalai pria (RTKP) dan rumahtangga yang dikepalai wanita (RTKW). Setiap tipe rumahtangga terbagi ke dalam empat struktur rumahtangga berdasarkan siklus hidup, yaitu: (1) Rumahtangga lajang, (2) Rumahtangga tanpa anak, (3) Rumahtangga tahap ekspansi demografis awal, dan (4) Rumahtangga tahap ekspansi demografis lanjut. Tipe rumahtangga dan struktur rumahtangga 
berdasarkan siklus hidup termasuk ke dalam struktur demografi rumahtangga yang diduga berpengaruh pada tingkat pendapatan yang diperoleh oleh rumahtangga. Tingkat pendapatan rumahtangga diduga berhubungan dengan tingkat ketahanan pangan rumahtangga. Pendapatan ini dilihat dari jumlah total pendapatan yang diperoleh dari anggota rumahtangga yang sudah bekerja dan mendapatkan penghasilan. Jika tingkat pendapatan rumahtangga termasuk ke dalam kategori tinggi, diduga akan mampu mengakses pangan yang lebih beragam. Sebaliknya, jika tingkat pendapatan rumahtangga termasuk ke dalam kategori rendah, diduga tidak mampu mengakses pangan yang beragam dikarenakan keterbatasan pendapatan yang diperolehnya. Pada RTKW, dimana yang mencari nafkah adalah wanita diduga terjadi diskriminasi pengupahan tenaga kerja wanita yang berpengaruh pada akses wanita dalam mendapatkan pangan sehingga dapat berdampak pada ketahanan pangannya. Diskriminasi pengupahan tersebut, semakin terasa pada RTKW yang memiliki balita, dimana ia harus mencari nafkah untuk dapat mencukupi kebutuhan hidup sehari-harinya namun di satu sisi, ia juga harus mengurus anak dan rumahtangganya. Hal tersebut menimbulkan banyaknya RTKW yang bekerja pada pekerjaan paruh waktu dan berupah rendah. Namun demikian, pada RTKW yang memiliki anak yang sudah bekerja, kebutuhan pangannya diduga akan dapat tercukupi karena adanya penambahan pendapatan di rumahtangga. Pada RTKP, diduga tidak terjadi diskriminasi pengupahan sehingga pendapatan yang diperoleh dapat digunakan untuk mengakses pangan dan non pangan sekaligus. Pangan yang tersedia dan berasal dari "membeli" akan terkait pada uang yang diperolehnya (baik dari hasil total pendapatan rumahtangga maupun hasil utang). Pangan yang tersedia di rumahtangga bisa berasal dari membelinya di pasar, barter, dan berasal dari pemberian orang lain. Selain tingkat pendapatan rumahtangga, diduga tingkat pendidikan pengelola pangan rumahtangga berhubungan dengan tingkat ketahanan pangan. Pengelola pangan rumahtangga adalah orang yang memutuskan untuk memilih dan membeli jenis bahan pangan serta jumlah pengeluaran untuk pangan. Oleh karena itu, diduga jika pengelola pangan memiliki tingkat pendidikan yang tinggi maka ia memiliki pengetahuan mengenai kandungan gizi dalam setiap jenis pangan dan dapat memanfaatkan pengetahuan pangan dan gizinya untuk dapat memutuskan untuk memilih dan membeli pangan dengan memperhatikan kandungan gizinya. Sebaliknya, diduga jika tingkat pendidikan pengelola pangan rendah maka ia kurang memiliki pengetahuan mengenai kandungan gizi dalam setiap jenis pangan sehingga dalam memutuskan untuk memilih dan membeli pangan tidak memperhatikan kandungan gizinya.

Tingkat ketahanan pangan rumahtangga baik pada RTKP dan RTKW diduga berbeda karena bergantung pada kemampuan rumahtangga dalam mengakses atau memenuhi pangan. Perbedaan tingkat ketahanan pangan pada kedua tipe rumahtangga tersebut dapat menimbulkan ketimpangan ketahanan pangan. Ketimpangan ketahanan pangan terjadi dimana pada rumahtangga yang tingkat ketahanan pangannya termasuk ke dalam kategori tahan pangan akan lebih terjamin kebutuhan pangannya daripada rumahtangga yang tingkat ketahanan pangannya termasuk ke dalam kategori tidak tahan pangan. Terwujudnya ketahanan pangan pada semua tipe rumahtangga akan berdampak pada perbaikan status gizi rumahtangga. Status gizi rumahtangga yang baik mencerminkan kualitas sumberdaya manusia yang ada di rumahtangga tersebut. Semakin baik status gizinya maka kualitas sumberdaya manusia pun dapat berkualitas sehingga mampu untuk melakukan aktivitasnya sehari-hari dengan baik. Untuk lebih jelasnya, kerangka pemikiran ini disajikan pada Gambar 2.

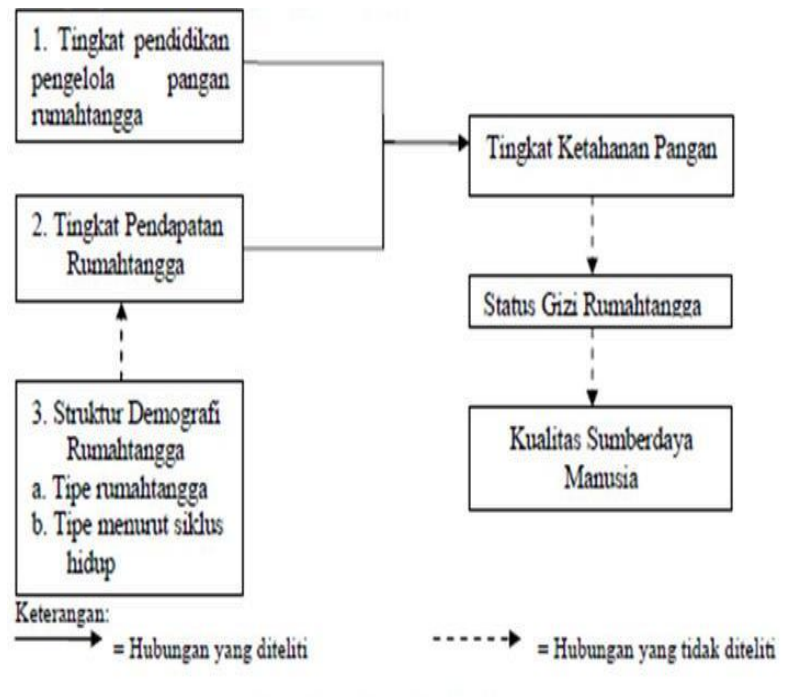

Gambar 2. Kerangka Pemikiran

\section{Hipotesis Penelitian}

Berdasarkan hasil kerangka pemikiran di atas, disusun hipotesis uji sebagai berikut:

1. Ketimpangan ketahanan pangan rumahtangga yang dikepalai pria (RTKP) dan rumahtangga yang dikepalai wanita (RTKW).

H0 : Tingkat ketahanan pangan RTKP sama dengan tingkat ketahanan pangan RTKW.

H1 : Tingkat ketahanan pangan RTKP tidak sama dengan tingkat ketahanan pangan RTKW.

2. Hubungan antara tingkat pendidikan pengelola pangan rumahtangga dengan tingkat ketahanan pangan rumahtangga.

a. Diduga ada hubungan antara tingkat pendidikan pengelola pangan RTKP dengan tingkat ketahanan pangan RTKP

b. Diduga ada hubungan antara tingkat pendidikan pengelola pangan RTKW dengan tingkat ketahanan pangan RTKW.

3. Hubungan antara tingkat pendapatan rumahtangga dengan tingkat ketahanan pangan rumahtangga. 


\section{PENDEKATAN LAPANG}

\section{Metode Penelitian}

Metode penelitian ini menggunakan pendekatan kuntitatif yang didukung oleh data kualitatif. Pendekatan kuantitatif yang dilakukan adalah dengan penelitian survai. Menurut Singarimbun dan Effendi (1989), penelitian survai adalah penelitian yang mengambil sampel dari satu populasi dan menggunakan kuesioner sebagai alat pengumpulan data yang pokok. Data kualitatif digunakan untuk menggali informasi yang sifatnya lebih mendalam serta untuk memperjelas gambaran tentang keadaan sosial yang diperoleh melalui pendekatan kuantitatif.

\section{Lokasi dan Waktu Penelitian}

Penelitian dilaksanakan di tiga rukun tetangga, yaitu RT 01, 02, 03 RW 03 Desa Cihideung Ilir, Kecamatan Ciampea, Kabupaten Bogor, Jawa Barat. Lokasi tiga rukun tetangga selanjutnya akan disebut sebagai Komunitas Jembatan Serong. Penentuan lokasi penelitian ini dilakukan secara sengaja (purposive) berdasarkan pertimbangan di lokasi tersebut masyarakatnya merupakan masyarakat transisi dari masyarakat pertanian ke masyarakat industri, terdapat masyarakat yang terdiri dari rumahtangga yang dikepalai pria (RTKP) dan rumahtangga yang dikepala wanita (RTKW), serta kemudahan akses transportasi sehingga memudahkan peneliti dalam memperoleh data dan informasi. Pengambilan data lapangan dilakukan dalam dua bulan, yaitu pada bulan Mei hingga Juni 2010.

\section{Teknik Pemilihan Responden dan Informan}

Populasi sampling dalam penelitian ini adalah rumahtangga yang berada di RT 01/03, RT 02/03, dan RT 03/3 di Desa Cihideung Ilir, Kecamatan Ciampea, Kabupaten Bogor, Jawa Barat. Jumlah kepala keluarga di tiga rukun tetangga tersebut sebanyak $246 \mathrm{KK}$, yang terdiri dari 215 RTKP dan 31 RTKW. Responden yang dipilih sebagai sampel dalam penelitian ini adalah rumahtangga baik RTKW maupun RTKP yang belum menikah atau lajang menjadi kepala rumahtangga (pencari nafkah) baik yang memiliki tanggungan maupun yang tidak memiliki tanggungan anggota rumahtangga lainnya, menikah namun belum memiliki anak atau tanggungan anggota rumahtangga lainnya, menikah (tapi pasangannya tidak mampu secara fisik atau mental untuk mengelola rumahtangganya) atau janda atau duda menjadi kepala rumahtangga (pencari nafkah) serta memiliki anak tertua berusia $<10$ tahun, serta menikah (tapi pasangannya tidak mampu secara fisik atau mental untuk mengelola rumahtangganya) atau janda atau duda (termasuk janda atau duda yang usianya $\geq 60$ tahun) menjadi kepala rumahtangga (pencari nafkah) serta memiliki anak tertua berusia $\geq 10$ tahun baik yang masih tinggal satu rumah maupun yang sudah menikah dan berpisah dengan orangtuanya. Selain itu, responden juga merupakan pengelola pangan rumahtangga. Pengelola pangan rumahtangga adalah orang yang memutuskan untuk memilih dan membeli jenis bahan pangan serta jumlah pengeluaran untuk pangan. Penentuan jumlah sampel menggunakan rumus slovin $^{2}$ dengan titik kritis 10 persen, yaitu:

$$
n=\frac{\mathrm{N}}{1+N e^{2}}
$$

Keterangan :

$\mathrm{n}$ : Ukuran Sampel,

$\mathrm{N}$ : Ukuran Populasi

$\mathrm{e}:$ Nilai kritis (batas ketelitian yang diinginkan)

Perhitungan sampel RTKP dan RTKW dengan menggunakan rumus slovin:

1) RTKP: $\mathrm{n}=\frac{N}{1+N \cdot e^{2}}=\frac{215}{1+215 \cdot 0,1^{2}}=\frac{215}{1+2,15}=\frac{215}{3,15}=68,25397 \approx 69$

2) $\mathrm{RTKW}: \mathrm{n}=\frac{N}{1+N \cdot e^{2}}=\frac{31}{1+31 \cdot 0,1^{2}}=\frac{31}{1+0,31}=\frac{31}{1,31}=23,66412 \approx 24$

Berdasarkan rumus slovin tersebut, jumlah responden yang menjadi sampel, yaitu 69 RTKP dan 24 RTKW. Responden dipilih dengan metode pengambilan sampel dengan cara acak sederhana (simple random sampling), yaitu pada rumahtangga yang dikepalai pria (RTKP) karena populasinya 215 RTKP maka dilakukan dengan cara melangkah dua hingga tiga nomor berdasarkan kerangka sampling RTKP yang telah dibuat dan diperoleh 69 RTKP dan pada rumahtangga yang dikepalai wanita (RTKW) karena populasinya 31 RTKW maka dilakukan pengundian dengan cara dikocok dari jumlah populasi tersebut sehingga diperoleh 24 RTKW. Informan dalam penelitian ini adalah ketua rukun tetangga (RT 01, 02, dan 03).

\section{Jenis Data dan Metode Pengumpulan Data}

Data yang dikumpulkan dalam penelitian ini terdiri dari data primer dan data sekunder. Pengumpulan data primer dilakukan dengan pendekatan kuantitatif dan kualitatif. Instrumen pengumpulan data yang dipakai adalah kuesioner dan wawancara mendalam. Data sekunder merupakan data yang didapatkan dari dokumen-dokumen tertulis baik yang berupa tulisan ilmiah ataupun dokumen laporan yang diterbitkan oleh instansi. Untuk menghindari adanya distorsi pesan dan untuk melengkapi informasi, maka setiap selesai melakukan wawancara mendalam dengan tineliti, peneliti meluangkan waktu untuk menuliskan kembali hasil wawancara dalam bentuk catatan harian.

\section{Teknik Pengolahan dan Analisis Data}

Data yang diperoleh dari kuesioner diolah secara kuantitatif dan kualitatif. Data kuantitatif disajikan dalam bentuk tabel frekuensi dan tabulasi silang. Pengolahan data kuantitatif dilakukan melalui tabulasi silang. Pertanyaan penelitian pertama mengenai kondisi ketahanan pangan di kedua tipe rumahtangga diperoleh dengan menggunakan data kuantitatif yang disajikan dalam tabel frekuensi. Pertanyaan penelitian kedua mengenai ketimpangan pangan di kedua tipe rumahtangga diketahui dengan menggunakan uji statistik Chi Square.

\footnotetext{
2 Wahidah. Metode Penelitian. Diakses dari http://www.damandiri.or.id/file/wahidahipbmetode.pdf 18 April 2010.
} 
Pertanyaan penelitian ketiga mengenai faktor yang berhubungan dengan ketahanan pangan diperoleh dari hasil pengolahan tabulasi silang. Tabulasi silang digunakan untuk mengetahui hubungan tingkat pendidikan pengelola pangan rumahtangga dengan tingkat ketahanan pangan rumahtangga dan hubungan tingkat pendapatan rumahtangga dengan tingkat ketahanan pangan rumahtangga. Selain itu, kondisi ketahanan pangan pada struktur rumahtangga berdasarkan siklus hidupnya diperoleh dari analisis secara kualitatif dari hasil wawancara mendalam dengan para responden. Setelah semua data pertanyaan pertama, kedua, dan ketiga dianalisis, dilakukan penafsiran atau pemaknaan hasil analisis tersebut. Penafsiran atau pemaknaan didukung dengan data kualitatif terhadap hasil analisa yang bertujuan untuk menarik kesimpulan penelitian berdasarkan perumusan masalah yang difokuskan dalam hipotesis penelitian. Selain itu, diperkuat dengan hasil analisis secara kualitatif dari hasil wawancara mendalam dengan para responden dan informan. Pengolahan dan analisis data kualitatif dilakukan dengan mereduksi (meringkas) data dengan menggolongkan, mengarahkan, membuang yang tidak perlu dan mengorganisasikan data sedemikian rupa sehingga sesuai dengan keperluan untuk menjawab pertanyaan analisis di dalam penelitian. Data hasil wawancara yang relevan dengan fenomena yang dianalisis, disajikan dalam bentuk kutipan-kutipan. Analisis data kualitatif dipadukan dengan hasil intrepretasi data kuantitatif.

\section{Kelemahan Kajian}

Di Amerika Serikat telah dikembangkan pengukuran ketahanan pangan yang dilakukan dengan metode kualitatif menggunakan alat kuesioner. Pertanyaan dalam kuesioner untuk berbagai indikator ini telah tertuang dalam Current Population Survey (CPS) Food Security Supplement di Amerika Serikat pada tahun 1995, yang menjadi dasar bagi pengukuran ketahanan pangan. Menurut Bickel et al. (2000) dalam Rahayu (2007), "modul inti" CPS (bagian kunci CPS Food Security Supplement) menanyakan tentang bermacam kondisi kejadian perilaku dan reaksi subjektif berupa: (1) kejadian mengurangi konsumsi orang dewasa dalam rumahtangga, atau berbagai akibat yang muncul dari mengurangi asupan makanan, (2) kejadian mengurangi makanan atau berbagai akibat yang muncul karena mengurangi asupan makanan pada anak-anak dalam rumahtangga, (3) kekhawatiran bahwa anggaran pangan rumahtangga atau ketersediaan pangan kemungkinan tidak mencukupi, dan (4) persepsi bahwa konsumsi orang dewasa atau anak-anak dalam rumahtangga tidak mencukupi dari segi kualitas, Tingkat ketahanan pangan secara kualitatif, diperoleh berdasarkan jawaban responden terhadap delapan belas pertanyaan ketahanan pangan dari kuesioner (Bickel et al., 2000 dalam Tobing, 2010), yaitu:

1. Terjamin: jika dua dari 18 pertanyaan yang ada, diantaranya dijawab dengan: sering, kadang-kadang, ya, hampir setiap bulan, beberapa bulan tetapi tidak setiap bulan.
2. Rawan kelaparan, dikelompokkan atas tiga kategori, yaitu:

a. Rawan dengan kelaparan tingkat ringan : jika 3-5 dari 18 pertanyaan yang ada diantaranya dijawab dengan: sering, kadang-kadang, ya, hampir setiap bulan, beberapa bulan tetapi tidak setiap bulan.

b. Rawan dengan kelaparan tingkat sedang: jika 6-8 dari 18 pertanyaan yang ada, diantaranya dijawab dengan: sering, kadang-kadang, ya, hampir setiap bulan, beberapa bulan tetapi tidak setiap bulan.

c. Rawan dengan kelaparan tingkat berat: jika $>9$ dari 18 pertanyaan yang ada, diantaranya dijawab dengan: sering, kadang-kadang, ya, hampir setiap bulan, beberapa bulan tetapi tidak setiap bulan.

Terdapat tiga kritikan terhadap tingkatan ketahanan pangan secara kualititatif yang diperkenalkan oleh Bickel, antara lain:

1. Kondisi tingkat ketahanan pangan yang termasuk ke dalam kategori "terjamin" tidak memadai bila hanya diukur dari responden yang menjawab dua dari delapan belas pertanyaan dengan jawaban sering, kadang-kadang, ya, hampir setiap bulan, beberapa bulan tetapi tidak setiap bulan. Hal tersebut dikarenakan pada delapan belas pertanyaan tersebut selain terdapat pilihan jawaban seperti diatas, juga terdapat pilihan jawaban "tidak", "tidak pernah", "tidak tahu", dan "hanya satu atau dua bulan" sehingga akan ada jawaban "tidak", "tidak pernah", "tidak tahu", dan "hanya satu atau dua bulan" yang justru sesuai untuk menggambarkan kondisi "terjamin". Berdasarkan alasa tersebut, ukuran tingkat ketahanan pangan menurut Bickel dapat diperbaiki dengan mempertimbangkan jawaban responden berupa "tidak", "tidak pernah", "tidak tahu", dan "hanya satu atau dua bulan".

2. Pertanyaan mengenai ketahanan pangan yang berjumlah delapan belas dan disusun oleh Bickel untuk menunjukkan tingkat kerawanan kelaparan ternyata mengabaikan gradasi keparahan kondisi kerawanan kelaparan. Oleh karena itu, delapan belas pertanyaan mengenai ketahanan pangan Bickel sebenarnya dapat disusun ulang berdasarkan gradasi keparahan kondisi kerawanan kelaparan yang menggambarkan skala kerawanan kelaparan semakin parah, misalnya gradasi pertanyaan yang menggambarkan kerawanan kelaparan tingkat ringan sampai dengan tingkat berat, dengan urutan sebagai berikut:

a. Pertanyaan yang menunjukkan rawan dengan kelaparan tingkat ringan adalah nomor 4 dan 14, yaitu:

Nomor 4. Dalam 1 tahun terakhir ini, Bapak/Ibu pernah hanya mampu menyediakan sedikit anggaran belanja untuk makanan balita, karena Bapak/Ibu kehabisan uang untuk membeli pangan? 

( ) Sering
( ) Kadang-kadang
( ) Tidak pernah
( ) Tidak tahu

Nomor 14. Dalam 1 tahun terakhir, mulai dari bulan ini ke belakang, apakah Bapak/Ibu ada mengurangi jumlah jajan anak dikarenakan tidak punya cukup uang untuk pangan?
( ) Iya
( ) Tidak
( ) Tidak tahu

b. Pertanyaan yang menunjukkan rawan dengan kelaparan tingkat sedang nomor $7,8,9,12,13$, 11 dan 10.

Nomor 7. Dalam 1 tahun terakhir ini, dimulai dari bulan ini ke belakang, apakah ada anggota keluarga ini yang pernah dikurangi pangannya dikarenakan ketiadaan uang?

( ) Iya

( ) Tidak, langsung ke pertanyaan nomor 9

( ) Tidak tahu, langsung ke pertanyaan nomor 9

Nomor 8. (Jika jawaban diatas, iya),berapa kali ini terjadi?

( ) Hampir setiap bulan

( ) Beberapa bulan tetapi tidak setiap bulan

( ) Hanya satu atau dua bulan

( ) Tidak tahu

Nomor 9. Dalam 1 tahun terakhir ini, apakah Bapak/Ibu pernah makannya sedikit karena ibu tidak punya cukup uang untuk membeli pangan?
( ) Iya
( ) Tidak
( ) Tidak tahu

Nomor 12. Dalam 1 tahun terakhir ini, apakah pernah, Bapak/Ibu atau anggota keluarga lainnya tidak makan dalam sehari dikarenakan tidak ada uang untuk memperoleh pangan?

( ) Iya

( ) Tidak, langsung ke pertanyaan no. 14

( ) Tidak tahu langsung ke pertanyaan no. 14
Nomor 13. (Jika jawaban diatas, iya), berapa kali ini terjadi?
( ) Hampir setiap bulan
( ) Beberapa bulan tetapi tidak setiap bulan
( ) Hanya satu atau dua bulan
( ) Tidak tahu

Nomor 11. Dalam 1 tahun terakhir ini, apakah ibu Bapak/Ibu mengalami penurunan berat badan dikarenakan tidak cukup biaya untuk pangan?
( ) Iya
( ) Tidak
( ) Tidak tahu

Nomor 10. Dalam 1 tahun terakhir ini, apakah Bapak/Ibu pernah merasa lapar tetapi tidak bisa makan dikarenakan Bapak/Ibu tidak mampu membeli pangan yang cukup?
( ) Iya
( ) Tidak
( ) Tidak tahu

c. Pertanyaan yang menunjukkan rawan dengan kelaparan tingkat sedang nomor $5,6,15,16,18$, dan 17.

Nomor 5. Dalam 1 tahun terakhir, apakah anak Bapak/Ibu dan keluarga pernah kurang makan karena tidak mampu membeli makanan?
( ) Sering
( ) Kadang-kadang
( ) Tidak pernah
( ) Tidak tahu

Nomor 6. Apakah dalam 1 tahun terakhir ini, anak Bapak/Ibu pernah kurang makan dikarenakan tidak mampu memberikan makanan yang cukup?
( ) Sering
( ) Kadang-kadang
( ) Tidak pernah
( ) Tidak tahu

Nomor 15. Dalam 12 bulan terakhir ini, apakah ada anak Bapak/Ibu yang tidak pernah rutin makannya karena tidak punya cukup uang untuk pangan?

( ) Iya 
( ) Tidak, langsung ke pertanyaan no. 17

( ) Tidak tahu, langsung ke pertanyaan no. 17

Nomor 16. (Jika jawaban diatas iya), berapa kali hal seperti ini terjadi?

( ) Hampir setiap bulan

( ) Beberapa bulan tetapi tidak setiap bulan

( ) Hanya satu atau dua bulan

( ) Tidak tahu

Nomor 18. Dalam 1 tahun terakhir ini, pernahkah anak Bapak/Ibu tidak makan selama sehari dikarenakan ketidakcukupan uang untuk membeli pangan?
( ) Iya
( ) Tidak
( ) Tidak tahu

Nomor 17. Dalam 1 tahun terakhir ini, pernahkah anak Bapak/Ibu menderita kelaparan tetapi anda tidak mampu membeli pangan lagi?
( ) Iya
( ) Tidak
( ) Tidak tahu

Selain pertanyaan yang menggambarkan gradasi tingkat kerawanan kelaparan, berdasarkan delapan belas pertanyaan tersebut terdapat pertanyaan yang dapat menunjukkan terjamin, yaitu pertanyaan nomor 1,2 , dan 3. Berikut pertanyaan nomor 1,2 , dan 3 :

Nomor 1. Apakah dalam 1 tahun terakhir Bapak/Ibu pernah merasa khawatir, pangan untuk keluarga sering habis, sementara Bapak/Ibu tidak punya uang untuk membelinya?
( ) Sering
( ) Kadang-kadang
( ) Tidak pernah
( ) Tidak tahu

Nomor 2. Dalam 1 tahun terakhir ini, pernahkah pangan yang dibeli habis dan Bapak/Ibu tidak punya uang untuk membelinya?
( ) Sering
( ) Kadang-kadang
( ) Tidak pernah
( ) Tidak tahu

Nomor 3. Dalam 1 tahun terakhir ini, pernahkan keluarga Bapak/Ibu tidak mampu makan yang seimbang?
( ) Sering
( ) Kadang-kadang
( ) Tidak pernah
() Tidak tahu

Berdasarkan penjabaran diatas, jika responden pertama menjawab pertanyaan nomor 4 dengan jawaban "sering" dibanding dengan responden kedua yang menjawab pertanyaan nomor 6 dengan jawaban yang sama, yaitu "sering", memiliki arti bahwa responden kedua mengalami kerawanan pangan yang lebih parah dibandingkan dengan responden pertama.

3. Bickel dalam membuat delapan belas pertanyaan mengenai ketahanan pangan tidak membedakan pertanyaan tentang persepsi (subyektif) dan pertanyaan faktual (kejadian). Pertanyaan mengenai ketahanan pangan tersebut terdiri dari 2 pertanyaan tentang persepsi (subyektif) dan 16 pertanyaan faktual (kejadian). Dalam hal kritiknya, pertanyaan persepsinya tidak terlalu jelas. Oleh karena itu, saran perbaikan terhadap pertanyaan Bickel adalah fokus saja pada pertanyaan-pertanyaan faktual (kejadian). Dalam pertanyaan Bickel, pertanyaan persepsi (subyektif) tercermin pada pertanyaan nomor 1 dan nomor 10, yaitu:

Nomor 1. Apakah dalam 1 tahun terakhir Bapak/Ibu pernah merasa khawatir, pangan untuk keluarga sering habis, sementara Bapak/Ibu tidak punya uang untuk membelinya?
( ) Sering
( ) Kadang-kadang
( ) Tidak pernah
( ) Tidak tahu

Nomor 10. Dalam 1 tahun terakhir ini, apakah Bapak/Ibu pernah merasa lapar tetapi tidak bisa makan dikarenakan Bapak/Ibu tidak mampu membeli pangan yang cukup?
( ) Iya
( ) Tidak
( ) Tidak tahu

Berdasarkan uraian tersebut, studi ini juga memiliki kelemahan serupa, karena belum mempertimbangkan tiga hal, yaitu:

1. Dalam menjawab delapan belas pertanyaan mengenai ketahanan pangan menurut Bickel hanya mempertimbangkan jawaban yang berupa: (1) sering, (2) kadang-kadang, (3) ya, (4) hampir setiap 
bulan, dan (5) beberapa bulan tetapi tidak setiap bulan, sedangkan jawaban yang berupa (6) tidak, (7) tidak pernah, (8) tidak tahu, dan (9) hanya satu atau dua bulan tidak dipertimbangkan padahal terdapat beberapa pertanyaan yang dijawab dengan jawaban tersebut.

2. Jawaban dari pertanyaan mengenai tingkat ketahanan pangan tidak berdasarkan gradasi tingkat kerawanan kelaparan sehingga tingkat ketahanan pangan hanya dilihat berdasarkan jawaban yang dijawab dengan (1) sering, (2) kadang-kadang, (3) ya, (4) hampir setiap bulan, dan (5) beberapa bulan tetapi tidak setiap bulan padahal sebenarnya tingkat ketahanan pangan rumahtangga dapat dilihat berdasarkan hasil jawaban berdasarkan gradasi pertanyaan.

3. Pertanyaan mengenai ketahanan pangan menurut Bickel ada yang termasuk ke dalam pertanyaan persepsi. Terdapat dua pertanyaan yang termasuk ke dalam pertanyaan persepsi. Pertanyaan persepsi tersebut tidak mempunyai pengertian yang sama sehingga setiap responden mengartikannya berbedabeda menurut persepsinya.

\section{GAMBARAN UMUM DESA CIHIDEUNG ILIR, KECAMATAN CIAMPEA, KABUPATEN BOGOR}

\section{Gambaran Umum Desa}

\section{Kondisi Fisik, Sarana dan Prasarana}

Desa Cihideung Ilir merupakan salah satu desa di wilayah Kecamatan Ciampea, Kabupaten Bogor, Provinsi Jawa Barat. Desa ini memiliki luas wilayah sebesar 178 hektare. Desa Cihideung Ilir termasuk dataran tinggi dan berada pada ketinggian 250 meter di atas permukaan laut dengan curah hujan 2 - 4 meter kubik. Secara administratif, Desa Cihideung Ilir terbagi ke dalam dua dusun, lima rukun warga (RW), dan 24 rukun tetangga (RT). Secara geografis, Desa Cihideung Ilir berbatasan dengan desa-desa lain di sekitarnya, yaitu terdiri dari:

\section{Sebelah Utara : Desa Cibanteng/Jalan Provinsi.}

2. Sebelah Timur: Desa Babakan/Kali Cihideung.

\section{Sebelah Selatan : Desa Cihideung Udik.}

\section{Sebelah Barat : Desa Cihideung Udik.}

Jika ditinjau dari letak geografisnya, Desa Cihideung Ilir mempunyai letak yang cukup strategis karena akses Desa Cihideung Ilir yang relatif dekat dengan Kampus Institut Pertanian Bogor. Oleh karena itu, Desa Cihideung Ilir termasuk ke dalam "Desa Lingkar Kampus". Kondisi ini memberikan keuntungan secara geografis dan memberikan pengaruh terhadap kondisi sosial ekonomi desa tersebut, baik secara langsung ataupun tidak langsung. Prasarana perhubungan yang terdapat di Desa Cihideung Ilir berupa jalan raya. Jarak dari desa ke pusat kecamatan adalah 4 kilometer, jarak dari desa ke ibukota kabupaten adalah 25 kilometer, dan jarak dari desa ke ibukota provinsi adalah 130 kilometer. Prasarana perhubungan yang berupa jalan raya yang baik memungkinkan tersedianya transportasi yang lancar bagi keberadaan mobil pribadi dan angkutan umum seperti, ojek dan odong-odong sebagai sarana transportasi di Desa Cihideung Ilir.

\section{Kependudukan, Pendidikan dan Mata Pencaharian}

Jumlah penduduk Desa Cihideung Ilir per Oktober 2009 adalah 9.393 jiwa dengan total jumlah kepala keluarga 2.490 KK. Jumlah penduduk angkatan kerja di Desa Cihideung Ilir terdiri dari penduduk usia yang bekerja dan penduduk usia kerja yang tidak bekerja. Jumlah penduduk usia dewasa usia kerja 5.263 jiwa atau 56,03 persen dari total jumlah penduduk secara keseluruhan. Jumlah penduduk usia kerja yang tidak bekerja 1.005 jiwa. Jumlah penduduk usia kerja yang bekerja lebih banyak daripada jumlah penduduk usia kerja yang tidak bekerja. Tingkat pendidikan masyarakat Desa Cihideung Ilir dapat dikatakan masih cukup rendah. Hal ini dapat dilihat dari besarnya angka penduduk yang hanya tamat SD sejumlah 2.780 orang dan yang tamat pasca sarjana hanya berjumlah 40 orang.

Mata pencaharian penduduk Desa Cihideung Ilir cukup bervariasi. Jumlah penduduk yang bekerja di sektor pertanian lebih sedikit dibandingkan dengan jumlah penduduk yang bekerja di sektor non-pertanian. Di sektor pertanian, dari keseluruhan penduduk hanya ada 548 orang yang bekerja sebagai petani. Sisanya bekerja di sektor non-pertanian. Mata pencaharian di sektor non-pertanian yang paling diminati adalah sebagai pedagang. Terdapat 945 orang bekerja sebagai pedagang dan pekerjaan-pekerjaan lain di sektor nonpertanian adalah sebagai pegawai negeri sipil, TNI/POLRI, pensiunan PNS/POLRI/TNI, swasta, buruh pabrik, pengrajin industri rumahtangga, tukang bangunan, penjahit, tukang las, tukang ojek, bengkel, sopir angkutan, dan lain-lain. Berdasarkan hal tersebut penduduk Desa Cihideung Ilir termasuk ke dalam kategori masyarakat transisi dimana mata pencahariannya sudah berubah dari sektor pertanian ke sektor non-pertanian.

\section{Karakteristik Rumahtangga Responden}

Karakteristik rumahtangga responden adalah kondisi atau keadaan spesifik rumahtangga yang berkaitan langsung dengan dirinya. Rumahtangga dalam penelitian ini terbagi ke dalam dua tipe, yaitu rumahtangga yang dikepalai pria (RTKP) dan rumahtangga yang dikepalai wanita (RTKW). Karakteristik rumahtangga dalam penelitian ini baik pada RTKP maupun RTKW dibedakan ke dalam tujuh kategori, yaitu usia seluruh anggota rumahtangga, jenis kelamin seluruh anggota rumahtangga, jenis kelamin pengelola pangan rumahtangga, tingkat pendidikan seluruh anggota rumahtangga, tingkat pendidikan pengelola pangan rumahtangga, status pekerjaan seluruh anggota rumahtangga, dan jenis pekerjaan seluruh anggota rumahtangga. Tabel 1 menunjukkan bahwa struktur rumahtangga terbagi ke dalam empat kategori berdasarkan siklus hidupnya, yaitu rumahtangga lajang, rumahtangga tanpa anak, rumahtangga tahap ekspansi demografis awal, dan rumahtangga tahap ekspansi 
demografis lanjut. RTKP dan RTKW masing-masing memiliki empat struktur rumahtangga.

\section{Tabel 1. Sebaran Jumlah dan Persentase Rumahtangga Berdasarkan Tipe dan Struktur Rumahtanga, Komunitas Jembatan Serong, 2010}

\begin{tabular}{|l|c|c|c|c|}
\hline \multirow{4}{*}{ Karakteristik Strultur Rumahtangga } & \multicolumn{2}{|c|}{$\begin{array}{c}\text { Rumahtangga yang } \\
\text { Dikepalai Pria (RTKP) } \\
\mathrm{n}=69\end{array}$} & $\begin{array}{c}\text { Rumahtangga yang Dikepalai } \\
\text { Wanita (RTKW) } \\
\mathrm{n}=24\end{array}$ \\
\cline { 2 - 5 } & $\begin{array}{c}\text { Jumlah } \\
\text { (numahtangga) }\end{array}$ & $\begin{array}{c}\text { Persentase } \\
(\%)\end{array}$ & $\begin{array}{c}\text { Jumlah } \\
\text { (numahtangga) }\end{array}$ & $\begin{array}{c}\text { Persentase } \\
(\%)\end{array}$ \\
\hline Lajang & 1 & 1,5 & 0 & 0 \\
\hline Tanpa Anak & 1 & 1,5 & 1 & 4,2 \\
\hline Tahap Ekspansi Demografis Awal & 15 & 21,7 & 1 & 4,2 \\
\hline Tahap Ekspansi Demografis Lanjut & 52 & 75,3 & 22 & 91,6 \\
\hline Total & 69 & 100 & 24 & 100 \\
\hline
\end{tabular}

Rumahtangga Responden yang Dikepalai Pria (RTKP) dan Rumahtangga Responden yang Dikepalai Wanita (RTKW) Berdasarkan Usia

Persentase usia seluruh anggota rumahtangga RTKP dan RTKW yang termasuk ke dalam kategori produktif lebih banyak daripada persentase usia seluruh anggota rumahtangga yang termasuk ke dalam kategori tidak produktif. Namun demikian, persentase usia seluruh anggota rumahtangga lebih banyak pada RTKW jika dibandingkan dengan RTKP. Berdasarkan Tabel 2 diketahui bahwa beban tanggungan pada RTKP lebih banyak dibandingkan dengan beban tanggungan RTKW. Hal tersebut disebabkan oleh banyaknya persentase usia seluruh anggota rumahtangga RTKP yang termasuk ke dalam kategori tidak produktif dibandingkan dengan RTKW. Berdasarkan rasio beban tanggungan, pada RTKW setiap 48 orang anggota rumahtangga yang termasuk ke dalam kategori tidak produktif ditanggung oleh 100 orang anggota rumahtangga yang termasuk ke dalam kategori produktif. Beban rasio tanggungan pada RTKP, yaitu setiap 60 orang anggota rumahtangga yang termasuk ke dalam kategori tidak produktif ditanggung oleh 100 orang anggota rumahtangga yang termasuk ke dalam kategori produktif.

Tabel 2. Sebaran Jumlah dan Persentase Rumahtangga yang Dikepalai Pria (RTKP) dan Rumahtangga yang Dikepalai Wanita (RTKW) Berdasarkan Usia, Komunitas Jembatan Serong, 2010

\begin{tabular}{|c|c|c|c|c|}
\hline \multirow[t]{2}{*}{ Karakteristik Rumahtangga } & \multicolumn{2}{|c|}{$\begin{array}{c}\text { Rumahtangga yang } \\
\text { Dikepalai Pria (RTKP) } \\
n=69\end{array}$} & \multicolumn{2}{|c|}{$\begin{array}{c}\text { Rumahtangga yang } \\
\text { Dikepalai Wanita (RTKW) } \\
n=24\end{array}$} \\
\hline & $\begin{array}{l}\text { Jumlah } \\
\text { (orang) }\end{array}$ & $\begin{array}{c}\text { Persentase } \\
(\%)\end{array}$ & $\begin{array}{l}\text { Jumlah } \\
\text { (orang) }\end{array}$ & $\begin{array}{c}\text { Persentase } \\
(\%)\end{array}$ \\
\hline \multicolumn{5}{|c|}{ Usia Seluruh Anggota Rumahtangga } \\
\hline Tidak Produktif & 154 & 37,4 & 36 & 32,1 \\
\hline Produktif & 258 & 62,6 & 76 & 67,9 \\
\hline Total & 412 & 100 & 112 & 100 \\
\hline
\end{tabular}

\section{Rumahtangga Responden yang Dikepalai Pria (RTKP) dan Rumahtangga Responden yang Dikepalai Wanita (RTKW) Berdasarkan Jenis Kelamin}

Persentase jenis kelamin seluruh anggota rumahtangga RTKP dan RTKW berbeda. Berdasarkan Table 3, jika dibandingkan antara RTKP dan RTKW maka pada RTKP persentase jenis kelamin seluruh anggota rumahtangga lebih banyak yang berjenis kelamin pria sedangkan pada RTKW persentase jenis kelamin seluruh anggota rumahtangga lebih banyak yang berjenis kelamin wanita. Jika dilihat berdasarkan pengelola pangan rumahtangga maka persentase pada RTKP dan RTKW lebih banyak yang berjenis kelamin wanita. Pada RTKP, pengelola pangan lebih banyak yang berjenis kelamin wanita diduga disebabkan oleh sibuknya pria dalam mencari nafkah sehingga kewenangan untuk mengelola pangan dilimpahkan ke wanita (pasangannya). Oleh karena itu, pengelola pangan rumahtangga pada hampir semua tipe rumahtangga berjenis kelamin wanita.

Tabel 3. Sebaran Jumlah dan Persentase Angoota dan Pengelola Pangan Rumahtangga yang Dikepalai Pria (RTKP) dan Rumahtangga yang Dikepalai Wanita (RTKW) Berdasarkan Jenis Kelamin, Komunitas Jembatan Serong, 2010

\begin{tabular}{|l|c|c|c|c|}
\hline \multirow{4}{*}{ Karakteristik Rumahtangga } & \multicolumn{2}{|c|}{$\begin{array}{c}\text { Rumahtangga yang } \\
\text { Dikepalai Pria (RTKP) } \\
\text { n=69 }\end{array}$} & $\begin{array}{c}\text { Rumahtangga yang } \\
\text { Dikepalai Wanita (RTKW) } \\
\text { n=24 }\end{array}$ \\
\cline { 2 - 5 } & $\begin{array}{c}\text { Jumlah } \\
\text { (orang) }\end{array}$ & $\begin{array}{c}\text { Persentase } \\
(\%)\end{array}$ & $\begin{array}{c}\text { Jumlah } \\
\text { (orang) }\end{array}$ & $\begin{array}{c}\text { Persentase } \\
(\%)\end{array}$ \\
\hline Jenis Kelamin Seluruh Anggota Rumaltanga \\
\hline Pria & 221 & 53,6 & 46 & 41,1 \\
\hline Wanita & 191 & 46,4 & 66 & 58,9 \\
\hline Total & 412 & 100 & 112 & 100 \\
\hline Jenis Kelamin Pengelola Pangan Rumahtangga \\
\hline Pria & 1 & 1,4 & 0 & 0 \\
\hline Wanita & 68 & 98,6 & 24 & 100 \\
\hline Total & 69 & 100 & 24 & 100 \\
\hline
\end{tabular}

\section{Rumahtangga Responden yang Dikepalai Pria (RTKP) dan Rumahtangga Responden yang Dikepalai Wanita (RTKW) Berdasarkan Tingkat Pendidikan}

Berdasarkan Tabel 4 menunjukkan bahwa persentase tingkat pendidikan seluruh anggota rumahtangga baik RTKP maupun RTKW lebih banyak yang termasuk ke dalam kategori rendah. Namun demikian, tingkat pendidikan seluruh anggota rumahtangga yang termasuk ke dalam kategori rendah lebih banyak pada RTKW dibandingkan dengan RTKP. Tingginya angka tingkat pendidikan seluruh anggota rumahtangga RTKW yang termasuk ke dalam kategori rendah diduga diakibatkan oleh terbatasnya pendapatan yang diperoleh rumahtangga tersebut. Tabel 4 juga menunjukkan bahwa persentase tingkat pendidikan pengelola pangan rumahtangga baik pada RTKP maupun RTKW lebih banyak yang termasuk ke dalam kategori tingkat pendidikan rendah bahkan pada RTKW tidak ada pengelola pangan yang tingkat pendidikannya termasuk ke dalam kategori tinggi. Tingginya tingkat pendidikan pengelola pangan RTKW yang termasuk ke dalam kategori rendah diduga berhubungan dengan tingkat ketahanan pangan. Hal tersebut disebabkan oleh adanya 
dugaan bahwa semakin tinggi tingkat pendidikan pengelola pangan maka akan semakin tinggi pula pengetahuan pangan dan gizinya sehingga akan berdampak pada semakin tahan ketahanan pangannya. Sebaliknya jika tingkat pendidikan pengelola pangan rendah maka diduga semakin rentan ketahanan pangannya karena diduga tingkat pendidikan pengelola pangan yang rendah berdampak pada kurangnya pengetahuan pangan dan gizi sehingga hal tersebut berpengaruh ketika memilih dan membeli jenis bahan pangan.

Tabel 4. Sebaran Jumlah dan Persentase Anggota dan Pengelola Pangan Rumahtangga yang Dikepalai Pria (RTKP) dan Rumahtangga yang Dikepalai Wanita (RTKW) Berdasarkan Tingkat Pendidikan, Komunitas Jembatan Serong, 2010

\begin{tabular}{|l|c|c|c|c|}
\hline \multirow{4}{*}{ Karakteristik Rumahtangga } & \multicolumn{3}{c|}{$\begin{array}{c}\text { Rumahtangga yang } \\
\text { Dikepalai Pria (RTKP) } \\
n=69\end{array}$} & $\begin{array}{c}\text { Rumahtangga yang } \\
\text { Dikepalai Wanita } \\
\text { (RTKW) } \\
\text { n=24 }\end{array}$ \\
\cline { 2 - 5 } & $\begin{array}{c}\text { Jumlah } \\
\text { (orang) }\end{array}$ & $\begin{array}{c}\text { Persentase } \\
(\%)\end{array}$ & $\begin{array}{c}\text { Jumlah } \\
\text { (orang) }\end{array}$ & $\begin{array}{c}\text { Persentase } \\
(\%)\end{array}$ \\
\hline Tingkat Pendidikan Seluruh Anggota Rumahtangga \\
\hline Rendah & 308 & 74,8 & 89 & 79,5 \\
\hline Sedang & 65 & 15,8 & 15 & 13,4 \\
\hline Tinggi & 39 & 9,5 & 8 & 7,1 \\
\hline Total & 412 & 100 & 112 & 100 \\
\hline Tingkat Pendidikan Pengelola Pangan Rumahtangga \\
\hline Rendah & 52 & 75,4 & 23 & 95,8 \\
\hline Sedang & 10 & 14,5 & 1 & 4,2 \\
\hline Tinggi & 7 & 10,1 & 0 & 0 \\
\hline Total & 69 & 100 & 24 & 100 \\
\hline
\end{tabular}

\section{Rumahtangga Responden yang Dikepalai Pria (RTKP) dan Rumahtangga Responden yang Dikepalai Wanita (RTKW) Berdasarkan Status Pekerjaan}

Berdasarkan Tabel 5 menunjukkan bahwa persentase status pekerjaan seluruh anggota rumahtangga yang termasuk ke dalam kategori tidak bekerja pada RTKP dan RTKW lebih banyak dibandingkan dengan persentase status pekerjaan seluruh anggota rumahtangga yang termasuk ke dalam kategori bekerja. Jika dibandingkan antar tipe rumahtangga, persentase status pekerjaan seluruh anggota rumahtangga yang termasuk ke dalam kategori tidak bekerja pada RTKP lebih banyak dibandingkan dengan persentase status pekerjaan seluruh anggota rumahtangga RTKW yang termasuk ke dalam kategori tidak bekerja. Pada RTKP, umumnya anggota rumahtangga yang tidak bekerja, yaitu wanita (ibu) dan anak-anak yang sudah termasuk kategori usia produktif namun tidak bekerja. Jumlah anggota rumahtangga yang bekerja melalui pendapatan yang diperolehnya digunakan untuk menanggung beban hidup anggota rumahtangga lainnya yang belum bekerja.
Tabel 5. Sebaran Jumlah dan Persentase Rumahtangga yang Dikepalai Pria (RTKP) dan Rumahtangga yang Dikepalai Wanita (RTKW) Berdasarkan Status Pekerjaan, Komunitas Jembatan Serong, 2010

\begin{tabular}{|l|c|c|c|c|}
\hline \multirow{3}{*}{ Karakteristik Rumahtangga } & \multicolumn{2}{|c|}{$\begin{array}{c}\text { Rumahtangga yang } \\
\text { Dikepalai Pria (RTKP) } \\
\mathrm{n}=69\end{array}$} & \multicolumn{2}{c|}{$\begin{array}{c}\text { Rumahtangga yang } \\
\text { Dikepalai Wanita (RTKW) } \\
\mathrm{n}=24\end{array}$} \\
\cline { 2 - 5 } & $\begin{array}{c}\text { Jumlah } \\
\text { (orang) }\end{array}$ & $\begin{array}{c}\text { Persentase } \\
(\%)\end{array}$ & $\begin{array}{c}\text { Jumlah } \\
\text { (orang) }\end{array}$ & $\begin{array}{c}\text { Persentase } \\
(\%)\end{array}$ \\
\hline Status Pekerjaan & 268 & 65 & 69 & 61,6 \\
\hline Tidak Bekerja & 144 & 35 & 43 & 38,4 \\
\hline Bekerja & 412 & 100 & 112 & 100 \\
\hline Total
\end{tabular}

Rumahtangga Responden yang Dikepalai Pria (RTKP) dan Rumahtangga Responden yang Dikepalai Wanita (RTKW) Berdasarkan Mata Pencaharian

Berdasarkan Tabel 6 diketahui bahwa persentase mata pencaharian anggota rumahtangga yang bekerja pada RTKP dan RTKW lebih banyak bekerja di sektor pertanian dibandingkan di sektor non-pertanian. Pada RTKP mata pencaharian di sektor pertanian, hanya terdapat 13,9 persen yang bekerja baik sebagai petani maupun buruh tani dan di RTKW terdapat 4,8 persen yang bekerja sebagai buruh tani. Mata pencaharian di sektor non-pertanian, baik pada RTKP maupun RTKW yang paling diminati adalah sebagai buruh pabrik. Di sektor non-pertanian, terdapat 25,7 persen RTKP bekerja sebagai buruh pabrik dan 33,3 persen RTKW bekerja sebagai buruh pabrik. Persentase mata pencaharian sebagai buruh pabrik lebih banyak dibandingkan dengan mata pencaharian lainnya, seperti PNS, karyawan swasta, petani, buruh tani, sopir/tukang ojek, berdagang, dan lain-lain (pembantu rumahtangga, guru, tukang urut, montir/teknisi, kenek/tukang parkir).

Tabel 6. Sebaran Jumlah dan Persentase Rumahtangga yang Dikepalai Pria (RTKP) dan Rumahtangga yang Dikepalai Wanita (RTKW) Berdasarkan Mata Pencaharian, Komunitas Jembatan Serong, 2010

\begin{tabular}{|l|c|c|c|c|}
\hline \multirow{2}{*}{ Karakteristik Rumahtangga } & \multicolumn{2}{|c|}{$\begin{array}{c}\text { Rumahtangga yang } \\
\text { Dikepalai Pria (RTKP) } \\
\mathrm{n}=69\end{array}$} & \multicolumn{2}{c|}{$\begin{array}{c}\text { Rumahtangga yang } \\
\text { Dikepalai Wanita (RTKW) } \\
\mathrm{n}=24\end{array}$} \\
\cline { 2 - 5 } & $\begin{array}{c}\text { Jumlah } \\
\text { (orang) }\end{array}$ & $\begin{array}{c}\text { Persentase } \\
(\%)\end{array}$ & $\begin{array}{c}\text { Jumlah } \\
\text { (orang) }\end{array}$ & $\begin{array}{c}\text { Persentase } \\
(\%)\end{array}$ \\
\hline PNS & 5 & 3,5 & 0 & 0 \\
\hline Karyawan Swasta & 12 & 8,3 & 5 & 11,9 \\
\hline Buruh Pabrik & 37 & 25,7 & 14 & 33,3 \\
\hline Petani & 2 & 1,4 & 0 & 0 \\
\hline Buruh Tani & 18 & 12,5 & 2 & 4,8 \\
\hline SopirTukang Ojek & 21 & 14,6 & 3 & 7,1 \\
\hline Berdagang & 21 & 14,6 & 12 & 28,6 \\
\hline $\begin{array}{l}\text { Lain-lain (pembantu rumahtangga, } \\
\text { guru, tukang urut, montir teknisi, } \\
\text { kenek tukang parkir) }\end{array}$ & 28 & 19,4 & 6 & 14,3 \\
\hline Total & 144 & 100 & 42 & 100 \\
\hline
\end{tabular}




\section{Rumahtangga Responden yang Dikepalai Pria (RTKP) dan Rumahtangga Responden yang Dikepalai Wanita (RTKW) Berdasarkan Tingkat Pendapatan}

Tabel 7 menunjukkan bahwa tingkat pendapatan rumahtangga RTKP berbeda jika dibandingkan dengan RTKW. Pada RTKP, tingkat pendapatan rumahtangga lebih banyak yang termasuk ke dalam kategori tinggi sedangkan pada RTKW, tingkat pendapatan rumahtangga lebih banyak yang termasuk ke dalam kategori rendah. Perbedaan tingkat pendapatan dikedua rumahtangga tersebut dikarenakan wanita yang bekerja hanya mampu mengakses pekerjaan-pekerjaan yang berupah rendah sedangkan pria yang bekerja mampu mengakses pekerjaan yang berupah tinggi sehingga pendapatan yang diperolehnya pun lebih tinggi daripada pendapatan yang diterima oleh wanita. Wanita yang bekerja umumnya bekerja di pabrik sebagai buruh pabrik. Upah yang diterima wanita yang bekerja di pabrik lebih sedikit daripada upah yang diterima oleh pria karena wanita yang bekerja di pabrik umumnya hanya paruh waktu.

\section{Tabel 7. Sebaran Jumlah dan Persentase Rumahtangga yang Dikepalai Pria (RTKP) dan Rumahtangga yang Dikepalai Wanita (RTKW) Berdasarkan Tingkat Pendapatan Rumahtangga, Komunitas Jembatan Serong, 2010}

\begin{tabular}{|l|c|c|c|c|}
\hline \multirow{3}{*}{$\begin{array}{c}\text { Karakteristik } \\
\text { Rumahtangga }\end{array}$} & \multicolumn{2}{|c|}{$\begin{array}{c}\text { Rumahtangga yang } \\
\text { Dikepalai Pria (RTK) } \\
\mathrm{n}=69\end{array}$} & $\begin{array}{c}\text { Rumahtangga yang } \\
\text { Dikepalai Wanita (RTKW) } \\
\mathrm{n}=24\end{array}$ \\
\cline { 2 - 5 } & $\begin{array}{c}\text { Jumlah } \\
\text { (rumahtangga) }\end{array}$ & $\begin{array}{c}\text { Persentase } \\
(\%)\end{array}$ & $\begin{array}{c}\text { Jumlah } \\
\text { (rumahtangga) }\end{array}$ & $\begin{array}{c}\text { Persentase } \\
(\%)\end{array}$ \\
\hline \multicolumn{5}{|c|}{ Tingkat Pendapatan Rumahtangga } \\
\hline Rendah & 19 & 28 & 12 & 50 \\
\hline Sedang & 25 & 36 & 6 & 25 \\
\hline Tinggi & 25 & 36 & 6 & 25 \\
\hline Total & 69 & 100 & 24 & 100 \\
\hline
\end{tabular}

\section{TINGKAT KETAHANAN PANGAN RUMAHTANGGA KOMUNITAS JEMBATAN SERONG}

Tingkat ketahanan pangan rumahtangga Komunitas Jembatan Serong termasuk ke dalam kategori "tahan pangan". Hal tersebut dikarenakan persentase rumahtangga yang tingkat ketahanan pangannya termasuk ke dalam kategori tahan pangan lebih banyak dibandingkan dengan persentase rumahtangga yang tingkat ketahanan pangannya termasuk ke dalam kategori lebih tidak tahan pangan. Tingkat ketahanan pangan rumahtangga Komunitas Jembatan Serong merupakan hasil dari penggabungan tingkat ketahanan pangan pada dua tipe rumahtangga, yaitu RTKP dan RTKW.

Jika dilihat berdasarkan tipe rumahtangga, tingkat ketahanan pangan RTKP berbeda dengan tingkat ketahanan pangan RTKW, dimana tingkat ketahanan pangan RTKP termasuk ke dalam kategori "tahan pangan" sedangkan tingkat ketahanan pangan RTKW termasuk ke dalam kategori "lebih tidak tahan pangan". Hal tersebut disebabkan karena tingkat pendidikan pengelola pangan dan tingkat pendapatan rumahtangganya RTKW lebih banyak yang termasuk ke dalam kategori rendah. Tingkat pendidikan pengelola pangan yang termasuk ke dalam kategori rendah mengakibatkan rumahtangga tersebut kurang mampu mengkonsumsi pangan yang bergizi karena tidak memiliki pengetahuan mengenai pangan dan gizi pada berbagai jenis bahan pangan. Selain itu, pengelola pangan rumahtangga juga tidak memiliki strategi untuk dapat mengakses pangan gizi tinggi dengan anggaran yang sesuai untuk pangan. Tingkat pendapatan rumahtangga yang termasuk ke dalam kategori rendah juga turut mengakibatkan rumahtangga tersebut menjadi tidak lebih tahan pangan. Hal tersebut terjadi karena pendapatan yang diperoleh rumahtangga tersebut tidak hanya digunakan untuk pangan tetapi juga digunakan untuk non pangan. Kebutuhan non pangan yang meningkat berdampak pada penurunan anggaran pangan yang pada akhirnya menurun juga aksesnya terhadap berbagai jenis pangan. Tingkat ketahanan pangan RTKP termasuk ke dalam kategori "tahan pangan" tetapi terdapat peristiwa tingkat ketahanan pangan yang termasuk ke dalam kategori "lebih tidak tahan pangan", yaitu pada struktur RTKP lajang sedangkan pada struktur RTKP tanpa anak, tahap ekspansi demografis awal, dan tahap ekspansi demografis lanjut tingkat ketahanan pangannya termasuk ke dalam kategori "tahan pangan". Tingkat ketahanan pangan RTKW termasuk ke dalam kategori "lebih tidak tahan pangan" tetapi jika dilihat berdasarkan struktur rumahtangga, terdapat peristiwa tingkat ketahanan pangan RTKW tahap ekspansi demografis lanjut termasuk ke dalam kategori "lebih tidak tahan pangan". Peristiwa lain yang juga terjadi pada RTKW, yaitu terdapat kejadian tingkat ketahanan pangan RTKW termasuk ke dalam kategori "tahan pangan", seperti yang terjadi pada RTKW tanpa anak dan RTKW tahap ekspansi demografis awal.

\section{Tabel 8. Sebaran Jumlah dan Persentase Rumahtangga Berdasarkan Tingkat Ketahanan Pangan Rumahtangga dan Tipe Rumahtangga. Komunitas Jembatan Serong. 2010}

\begin{tabular}{|c|c|c|c|c|c|}
\hline \multirow{3}{*}{$\begin{array}{c}\text { Tingkat } \\
\text { Ketahanan } \\
\text { Pangan } \\
\text { Rumahtangga }\end{array}$} & \multicolumn{4}{|c|}{ Tipe Rumahtangga } & \multirow[b]{3}{*}{ Jumlah } \\
\hline & \multicolumn{2}{|c|}{ RTKP } & \multicolumn{2}{|c|}{ RTKW } & \\
\hline & $\begin{array}{c}\text { Jumlah } \\
\text { (rumahtangga) }\end{array}$ & \begin{tabular}{|c}
$\begin{array}{c}\text { Persentase } \\
(\%)\end{array}$ \\
\end{tabular} & $\begin{array}{c}\text { Jumlah } \\
\text { (rumahtangga) }\end{array}$ & $\begin{array}{c}\text { Persentase } \\
(\%)\end{array}$ & \\
\hline $\begin{array}{l}\text { Tidak Tahan } \\
\text { Pangan } \\
\end{array}$ & 28 & 40,6 & 13 & 54.2 & 41 \\
\hline Tahan Pangan & 41 & 59,4 & 11 & 45,8 & 52 \\
\hline Jumlah & 69 & 100 & 24 & 100 & 93 \\
\hline
\end{tabular}

Perbedaan tingkat ketahanan pangan RTKP dan RTKW, dimana tingkat ketahanan pangan RTKP termasuk ke dalam kategori "tahan pangan" dan tingkat ketahanan pangan RTKW termasuk ke dalam kategori "lebih tidak tahan pangan" tidak menimbulkan ketimpangan ketahanan pangan. Dalam hal ini, ketimpangan ketahanan pangan adalah kondisi kurang terpenuhinya pangan yang tercermin dari tidak meratanya jumlah pangan yang tersedia, distribusi, dan konsumsi pangan. Berdasarkan hasil uji statistik Chi Square diketahui bahwa tingkat ketahanan pangan RTKP sama dengan

210 Fathonah, Tri Yuliyanti. et. al. Tingkat Ketahanan Pangan pada Rumahtangga 
tingkat ketahanan pangan RTKW, artinya tingkat ketahanan pangan RTKP dan RTKP sama. Hasil perhitungan Chi Square menunjukkan bahwa $\chi 20(\chi$ hitung $=1,034)$ lebih kecil daripada $\chi^{2}(\chi$ tabel $=3,84)$. Sesuai dengan hipotesa uji, jika $\chi$ hitung lebih kecil daripada $\chi$ tabel maka H0 diterima, artinya tingkat ketahanan pangan RTKP sama dengan tingkat ketahanan pangan RTKW. Oleh karena itu, tidak terjadi ketimpangan ketahanan pangan di kedua rumahtangga tersebut.

Tabel 9. menunjukkan upaya yang dilakukan oleh RTKP yang "lebih tidak tahan pangan" dalam mengatasi kekurangan pangan dari yang paling sering hingga jarang dilakukan adalah dengan mengutang ke warung, meminjam uang, membeli makanan yang murah, meminta ke saudara, dan bekerja lebih keras. Berbeda dengan RTKP, pada RTKW yang "lebih tidak tahan pangan" upaya yang dilakukan dari yang paling sering hingga jarang dilakukan untuk mengatasi kekurangan pangan adalah dengan meminjam uang, meminta ke saudara, mengutang ke warung, membeli makanan yang murah, bekerja lebih keras, mengurangi makanan jajanan, dan mengurangi frekuensi makan. Upaya untuk mengatasi kekurangan pangan yang paling sering dilakukan RTKP yang "lebih tidak tahan pangan" adalah dengan mengutang ke warung sedangkan pada RTKW yang "lebih tidak tahan pangan" adalah dengan meminjam uang. Berdasarkan hal tersebut terlihat bahwa RTKP yang "lebih tidak tahan pangan" lebih senang mengutang ke warung dan langsung mendapatkan jenis bahan pangan yang diinginkan sedangkan pada RTKW yang "lebih tidak tahan pangan" lebih senang meminjam uang karena dengan meminjam uang dapat membuat anggaran untuk pangan yang sesuai dengan pinjaman uang yang diperoleh.

Tabel 9. Upaya Rumahatangga dalam Mengatasi Kekurangan Pangan Berdasarkan Rumahtangga yang lebilh tidak tahan pangan

\begin{tabular}{|l|c|c|c|c|}
\hline \multirow{2}{*}{$\begin{array}{c}\text { Upaya Rumah Tangga Mengatasi } \\
\text { Kekurangan Pangan }\end{array}$} & \multicolumn{2}{|c|}{$\begin{array}{c}\text { RTKP } \\
\mathrm{n}=28\end{array}$} & \multicolumn{2}{c|}{$\begin{array}{c}\text { RTKW } \\
\mathrm{n}=13\end{array}$} \\
\cline { 2 - 5 } & $\begin{array}{c}\text { Jumlah } \\
\text { (orang) }\end{array}$ & $\begin{array}{c}\text { Persentase } \\
(\%)\end{array}$ & $\begin{array}{c}\text { Jumlah } \\
\text { (upaya) }\end{array}$ & $\begin{array}{c}\text { Persentase } \\
(\%)\end{array}$ \\
\hline Membeli makanan yang murah & 7 & 14,6 & 3 & 10,7 \\
\hline Meminjam uang & 16 & 33 & 8 & 28,6 \\
\hline Mengutang ke warung & 17 & 36 & 5 & 17,8 \\
\hline Meminta ke saudara & 4 & 8 & 6 & 21,4 \\
\hline Mengurangi makanan jajanan & 0 & 0 & 1 & 3,6 \\
\hline Mengurangi frekuensi makan & 0 & 0 & 1 & 3,6 \\
\hline Bekerja lebilh keras & 1 & 2,1 & 3 & 10,7 \\
\hline Tidak Melakukan apa-apa & 3 & 6,3 & 1 & 3,6 \\
\hline
\end{tabular}

Strategi yang dilakukan oleh RTKP dan RTKW untuk mengatasi kekurangan pangan berbeda-beda. Pada RTKP, strategi yang dilakukan dengan meminjam uang dan mengutang ke warung sedangkan pada RTKW, dilakukan dengan meminjam uang dan meminta ke saudara. Baik RTKP maupun RTKW sama-sama mempunyai strategi dengan meminjam uang karena strategi tersebut paling mudah untuk dilakukan. Peminjaman uang umumnya kepada bank keliling yang setiap hari berkeliling di wilayah Jembatan Serong. Jika meminjam kepada tetangga atau saudara kondisi keuangannya sama sehingga meminjam kepada bank keliling. Meminjam uang, membeli makanan yang murah, dan mengutang ke warung merupakan strategi lain yang dilakukan oleh RTKP dan RTKW. Membeli makanan murah, yaitu dengan membeli sembako murah di ketua RT (Rukun Tetangga) yang berasal dari kantor kepala desa. Sembako murah tersebut berupa beras miskin (raskin) yang disubsidi oleh pemerintah.

\section{HUBUNGAN TINGKAT PENDIDIKAN \\ PENGELOLA PANGAN DAN TINGKAT PENDAPATAN RUMAHTANGGA DENGAN TINGKAT KETAHANAN PANGAN RUMAHTANGGA}

Berdasarkan tabulasi silang Tabel 10 menunjukkan bahwa ada hubungan antara tingkat pendapatan RTKP dengan tingkat ketahanan pangan RTKP dan hal tersebut sesuai dengan hipotesis uji. Hubungan antara tingkat pendapatan RTKP dengan tingkatan ketahanan pangan RTKP adalah hubungan yang positif, artinya semakin tinggi tingkat pendidikan pengelola pangan RTKP maka akan semakin tinggi pula tingkat ketahanan pangan RTKP. Tabel 10 menggambarkan bahwa semakin meningkat tingkat pendidikan pengelola pangan RTKP maka tingkat ketahanan pangannya juga akan semakin meningkat. Berbeda dengan RTKP, jenis kelamin pengelola pangan RTKW seluruhnya berjenis kelamin wanita dan tingkat pendidikan pengelola pangan RTKW lebih banyak yang termasuk ke dalam kategori rendah, sisanya termasuk ke dalam kategori sedang dan tidak ada yang termasuk ke dalam kategori tinggi. Tabulasi silang Tabel 10 menunjukkan bahwa terdapat hubungan antara tingkat pendidikan pengelola pangan RTKW dengan tingkat ketahanan pangan RTKW. Hubungan tersebut menunjukkan bahwa semakin tinggi tingkat pendidikan pengelola pangan RTKW maka akan semakin tinggi pula tingkat ketahanan pangan.

Tabel 10. Sebaran Jumlah dan Persentase Rumahtangga Berdasarkan Tingkat Pendidikan Pengelola Pangan RTKP. RTKW dan Tingkat Ketahanan Pangan Rumah Tangga, Komunitas Jembatan Serong, 2010

\begin{tabular}{|c|c|c|c|c|c|c|}
\hline \multirow{4}{*}{$\begin{array}{c}\text { Tingkat Ketahanan } \\
\text { Pangan Rumahtangga }\end{array}$} & \multicolumn{3}{|c|}{ Tingkat Pendidikan } & \multicolumn{2}{|c|}{ Tingkat Pendidikan Pengelola } & \\
\cline { 2 - 6 } & Pengelola Pangan RTKP & \multicolumn{2}{|c|}{ Pangan RTKW } & \multirow{2}{*}{ Jumlah } \\
\hline & 24 & 3 & 1 & 13 & 0 & 41 \\
Tidak Tahan Pangan & $(46,2)$ & $(30)$ & $(14,3)$ & $(56,5)$ & $(0)$ & $(44)$ \\
\hline & 28 & 7 & 6 & 10 & 1 & 52 \\
Tahan Pangan & $(53,8)$ & $(70)$ & $(85,7)$ & $(43,5)$ & $(100)$ & $(56)$ \\
\hline & 52 & 10 & 7 & 23 & 1 & 93 \\
Jumlah & $(100)$ & $(100)$ & $(100)$ & $(100)$ & $(100)$ & $(100)$ \\
\hline
\end{tabular}

Berdasarkan hasil tabulasi silang pada Tabel 11 menggambarkan bahwa terdapat hubungan antara tingkat pendapatan RTKP dengan tingkat ketahanan pangan RTKP. Hubungan tersebut menunjukkan semakin tinggi tingkat pendapatan RTKP maka tingkat ketahanan pangan RTKP akan semakin tahan pangan. Sebesar 42 persen RTKP yang tingkat pendapatannya 
termasuk kategori rendah memiliki tingkat ketahanan pangan yang tahan pangan, jumlah RTKP yang tahan pangan semakin meningkat seiring meningkatnya tingkat pendapatan RTKP. Sebesar 52 persen RTKP yang tingkat pendapatannya termasuk ke dalam kategori sedang memiliki tingkat ketahanan pangan yang tahan pangan dan semakin meningkat pada RTKP yang tingkat pendapatannya termasuk ke dalam kategori tinggi yaitu sebesar 80 persen termasuk ke dalam kategori tahan pangan. Hubungan antara tingkat pendapatan rumahtangga dengan tingkat ketahanan pangan rumahtangga juga terjadi pada RTKW. Berdasarkan hasil tabulasi silang Tabel 11 menggambarkan bahwa persentase RTKW yang termasuk ke dalam kategori tahan pangan semakin meningkat pada setiap tingkatan pendapatan RTKW. Sebesar 42 persen RTKW yang tingkat pendapatannya termasuk ke dalam kategori rendah, tingkat ketahanan pangannya adalah tahan pangan. Persentase RTKW yang termasuk tahan pangan menurun pada tingkat pendapatan yang termasuk kategori sedang menjadi hanya 33 persen. Persentase tersebut meningkat kembali pada tingkat pendapatan yang termasuk ke dalam kategori tinggi menjadi 67 persen yang termasuk ke dalam tahan pangan.

\section{Tabel 11. Sebaran Jumlah dan Persentase Rumahtangoga Berdasarkan Tingkat Pendapatan RTKP, RTKW dan Tingkat Ketahaman Pangan Rumah Tangoga, Komunitas Jenbatan Serong, 2010}

\begin{tabular}{|c|c|c|c|c|c|c|c|}
\hline \multirow{2}{*}{$\begin{array}{c}\text { Tingkat Ketahanan } \\
\text { Pangan }\end{array}$} & \multicolumn{2}{|c|}{ Tingkat Pendapatan RTKP } & \multicolumn{2}{c|}{ Tingkat Pendapatan RTKW } & \multirow{2}{*}{} \\
\cline { 2 - 7 } & Rendah & Sedang & Tinggi & Rendah & Sedang & Tinggi & Jumlah \\
\hline \multirow{3}{*}{ Tidak Tahan Pangan } & 11 & 12 & 5 & 7 & 4 & 2 & 41 \\
\hline & $(58)$ & $(48)$ & $(20)$ & $(58)$ & $(67)$ & $(33)$ & $(44)$ \\
\hline Tahan Pangan & 8 & 13 & 20 & 5 & 2 & 4 & 52 \\
\hline & $(42)$ & $(52)$ & $(80)$ & $(42)$ & $(33)$ & $(67)$ & $(56)$ \\
\hline Jumlah & 19 & 25 & 25 & 12 & 6 & 6 & 93 \\
& $(100)$ & $(100)$ & $(100)$ & $(100)$ & $(100)$ & $(100)$ & $(100)$ \\
\hline
\end{tabular}

\section{KONDISI KETAHANAN PANGAN PADA RUMAHTANGGA KOMUNITAS JEMBATAN SERONG}

\section{Kasus RTKW Tanpa Anak}

Rumahtangga yang termasuk ke dalam kategori ini adalah St (62 tahun). St adalah seorang janda yang hidup sendiri dan tidak memiliki anak. Ia tidak bekerja namun kehidupan sehari-harinya ia gantungkan dari hasil mengontrakkan sebagian rumahnya. St merupakan pengelola pangan di rumahtangganya dan tingkat pendidikannya termasuk ke dalam kategori rendah karena St tidak pernah menjalani sekolah formal hanya pernah menjalani sekolah agama. Pendapatan yang diperolehnya dari mengontrakkan sebagian rumahnya adalah Rp. 100.000 per bulan. Tingkat ketahanan pangan RTKW tanpa anak termasuk ke dalam kategori "tahan pangan" karena hanya sedikit ditemukan bukti ketidaktahanan pangan, dimana rumahtangga ini sering merasa khawatir pangan untuk keluarganya habis sementara ia tidak mempunyai uang untuk membelinya lagi. Dalam setahun terakhir rumahtangga ini tidak pernah mengalami kehabisan pangan. St juga tidak pernah makan sedikit dan mengurangi porsi makannya bahkan merasa lapar namun tidak bisa makan karena tidak mempunyai cukup uang untuk membeli pangan. St selalu mengkonsumsi pangan cukup dan tidak kekurangan sehingga berat badannya dalam setahun terakhir ini tidak turun. Jika berat badannya turun bukan disebabkan karena ia tidak mampu makan yang cukup tetapi karena sakit atau tidak nafsu makan. Selain itu, St juga tidak pernah tidak mampu makan selama sehari karena jika St sudah tidak memiliki uang untuk membeli pangan, ia akan meminta ke saudaranya sehingga kebutuhan pangannya tercukupi.)

\section{Kasus RTKW Tahap Ekspansi Demografis Awal}

Rumahtangga yang termasuk RTKW tahap ekspansi demografis awal adalah Si (27 tahun). Si merupakan kepala keluarga yang memiliki anak tertua berusia 7 tahun sekaligus pengelola pangan di rumahtangganya. Tingkat pendidikan Si termasuk ke dalam kategori sedang. Si tinggal bersama orangtua, kakak, dan adiknya. Rumahtangga ini terdiri dari enam orang, dimana dua orang bekerja, yaitu Si dan ibunya. Si bekerja sebagai buruh pabrik dan ibunya bekerja sebagai pembantu rumahtangga yang pulang dua minggu sekali. Si sering kerja lembur di pabrik untuk mendapatkan tambahan pendapatan. Pendapatan rumahtangga ini adalah Rp. 2.200 .000 per bulan. Tingkat ketahanan pangan RTKW tahap ekspansi demografis awal termasuk ke dalam kategori "tahan pangan" karena ditemukan sedikit bukti ketidaktahanan pangan (rumahtangga ini sering merasa khawatir pangan untuk keluarganya habis sementara ia tidak mempunyai uang untuk membelinya lagi bahkan ia pernah mengalami pangan yang dibelinya habis). Upaya yang ia lakukan untuk mengatasi masalah ini dengan mengutang ke warung. Walaupun begitu, rumahtangga ini selalu mengkonsumsi makanan yang seimbang dan tidak pernah mengurangi jumlah jajan bagi anaknya karena menurutnya kebutuhan pangan anaknya merupakan prioritas utama sehingga anak Si tidak pernah mengalami kurang makan, kelaparan atau tidak makan selama sehari. Seluruh anggota rumahtangga Si, tidak pernah mengalami tidak makan selama sehari atau dikurangi porsi makannya. Dalam setahun terakhir, $\mathrm{Si}$ tidak pernah makannya sedikit dan tidak pernah merasa lapar namun tidak bisa makan karena ia tidak punya cukup uang.

\section{Kasus RTKW Tahap Ekspansi Demografis Lanjut}

Tingkat ketahanan pangan RTKW tahap ekspansi demografis lanjut lebih banyak yang termasuk ke dalam kategori lebih tidak tahan pangan daripada yang termasuk ke dalam kategori tahan pangan. Salah satu RTKW tahap ekspansi demografis lanjut yang tingkat ketahanan pangannya termasuk ke dalam kategori lebih tidak tahan pangan adalah $\mathrm{Sp}$ (40 tahun). Sp hidup bersama ketiga anaknya dan dua orang cucunya. Sp merupakan pengelola pangan di rumahtangganya dan tingkat pendidikannya termasuk ke dalam kategori rendah. Sehari-harinya Sp bekerja dengan berdagang gado-gado di kantin Kampus IPB dan dibantu oleh dua orang anaknya karena ada seorang anaknya yang 
berkerja sebagai buruh pabrik. Pendapatan yang diperoleh rumahtangga ini adalah Rp. 2.100.000 per bulan. Tingkat ketahanan pangan rumahtangga ini termasuk ke dalam kategori "lebih tidak tahan pangan" karena ada beberapa bukti yang menunjukkan ketidaktahanan pangan, yaitu rumahtangga ini sering merasa khawatir pangan untuk keluarganya habis sementara ia tidak mempunyai uang untuk membelinya lagi dan kadang-kadang mengkonsumsi makanan yang seimbang karena keterbatasan pendapatan yang diperolehnya. Namun, Sp tidak pernah mengurangi jumlah jajan anaknya. Baginya, kebutuhan pangan untuk anak dan cucunya merupakan prioritas utama. Oleh karena itu, anak dan cucunya tidak pernah kurang makan, tidak pernah mengalami kelaparan bahkan sampai tidak makan selama sehari karena tidak mempunyai uang yang cukup untuk membeli makanan. Sp juga tidak pernah mengurangi anggaran belanja untuk cucunya yang masih balita. Seluruh anggota rumahtangga SP selalu rutin makan dan tidak pernah tidak makan selama sehari karena tidak mempunyai uang yang cukup untuk membeli pangan. Dalam setahun terakhir, Sp tidak pernah makannya sedikit dan tidak pernah merasa lapar namun tidak bisa makan karena ia tidak punya cukup uang. Walaupun tingkat ketahanan RTKW tahap ekspansi demografis lanjut termasuk ke dalam kategori "lebih tidak tahan pangan" namun ternyata ada yang tingkat ketahanan pangannya termasuk ke dalam kategori "tahan pangan". Salah satunya adalah Om (50 tahun). Om adalah janda dengan dua orang anak. Om bekerja dengan berdagang menjual sayuran dan anak pertamanya bekerja dengan berdagang, membuka warung kecil. Om merupakan pengelola pangan di rumahtangganya dan tingkat pendidikannya termasuk ke dalam kategori rendah. Pendapatan yang diperoleh rumahtangga ini adalah $\mathrm{Rp}$ 1.200.000 per bulan. Tingkat ketahanan pangan rumahtangga ini termasuk ke dalam kategori "tahan pangan" karena terbukti hanya sedikit yang menunjuk ketidaktahanan pangan, yaitu rumahtangga ini sering merasa khawatir pangan untuk keluarganya habis sementara ia tidak mempunyai uang untuk membelinya lagi namun ia tidak pernah mengalami pangan yang dibelinya habis. Rumahtangga ini selalu mengkonsumsi makanan yang seimbang karena salah satu anaknya cacat mental dan selalu ingin makanan yang lengkap (nasi, sayur, daging/ikan, tahu, dan tempe). Om tidak pernah mengurangi jumlah jajan anaknya. Selain itu, anak Om tidak pernah kurang makan, tidak pernah mengalami kelaparan dan tidak makan selama sehari karena tidak mempunyai uang yang cukup untuk membeli makanan. Seluruh anggota rumahtangga Om selalu rutin makan dan tidak pernah tidak makan selama sehari karena tidak mempunyai uang yang cukup untuk membeli pangan. Dalam setahun terakhir, Om tidak pernah makannya sedikit dan tidak pernah merasa lapar namun tidak bisa makan karena ia tidak punya cukup uang. Jika ia sudah tidak memiliki cukup uang untuk membeli bahan pangan, ia akan meminjam uang pada bank keliling dan membayar cicilan sebesar Rp 2000 per hari untuk melunasi hutangnya.

\section{Kasus RTKP Lajang}

RTKP lajang yang ditemukan di lokasi penelitian dikepalai oleh anak tertua karena kedua orangtuanya sudah meninggal. RTKP ini terdiri dari enam anggota rumahtangga, dimana hanya tiga orang yang bekerja dan ketiganya bekerja sebagai sopir, dua orang menganggur, dan satu orang masih sekolah. Pengelola pangan di rumahtangga ini adalah adik perempuan kepala keluarga tersebut dan tingkat pendidikannya termasuk ke dalam kategori rendah. Ia adalah Un (23 tahun). Pendapatan yang diperoleh rumahtangga ini adalah Rp 2.700.000 per bulan. Tingkat ketahanan pangan rumahtangga ini termasuk ke dalam kategori "lebih tidak tahan pangan" karena terdapat beberapa bukti ketidaktahanan pangan, yaitu rumahtangga ini kadang-kadang merasa khawatir pangan untuk anggota rumahtangganya habis dan RTKP tipe ini pernah merasa lapar namun tidak bisa makan karena tidak mampu membeli pangan yang cukup. Selain itu, RTKP tipe ini juga tidak mampu untuk mengkonsumsi makanan yang seimbang sesuai dengan kandungan zat gizi yang diperlukan oleh tubuh. RTKP tipe ini hanya mampu menyediakan pangan yang dapat dibeli sesuai dengan pendapatan yang diperolehnya sehingga tidak memperhatikan kandungan gizi dalam pangan yang dibelinya. Namun, RTKP ini tidak pernah mengalami kekurangan pangan karena pengelola pangan membeli makanan yang dapat diakses olehnya sesuai dengan pendapatan yang diperoleh rumahtangga tersebut.

\section{Kasus RTKP Tanpa Anak}

RTKP tanpa anak yang ditemukan di lokasi penelitian adalah $\mathrm{Au}$ (67 tahun). Au hidup seorang diri dan kebutuhan sehari-harinya ia penuhi dari pendapatannya sebagai buruh tani. Au merupakan pengelola pangan di rumahtangganya dan tingkat pendidikannya termasuk ke dalam kategori rendah. Pendapatan yang diperoleh rumahtangga ini adalah Rp 210.000 per bulan. Dengan pendapatan yang diperolehnya, ia dapat mencukupi kebutuhan gizi tubuhnya dengan mengkonsumsi makanan yang seimbang. Tingkat ketahanan pangan rumahtangga ini termasuk ke dalam kategori "tahan pangan" karena hanya sedikit bukti ketidaktahanan pangan, yaitu rumahtangga ini pernah makannya sedikit karena tidak mempunyai cukup uang untuk membeli pangannya.

\section{Kasus RTKP Tahap Ekspansi Demografis Awal}

Salah satu RTKP tahap ekspansi demografis awal yang tingkat ketahanan pangannya termasuk ke dalam kategori "lebih tidak tahan pangan" adalah Rn (41 tahun). Rumahtangga ini hanya memiliki satu orang anak yang berusia 7 tahun. Rn merupakan pengelola pangan di rumahnya dan tingkat pendidikannya termasuk ke dalam kategori rendah. Rn bekerja sebagai buruh di Pabrik Kecap dan suaminya bekerja sebagai sopir. Pendapatan yang diperoleh rumahtangga ini adalah Rp 493.000 per bulan. Tingkat ketahanan pangan rumahtangga ini termasuk ke dalam kategori "lebih tidak tahan pangan" karena banyak ditemukan bukti ketidaktahanan pangan, antara lain rumahtangga ini kadang-kadang merasa khawatir pangan yang ada di 
rumahnya habis sementara ia tidak memiliki cukup uang untuk membelinya lagi bahkan ia pernah mengalami hal tersebut dalam setahun terakhir. Selain itu, Rn juga pernah merasa lapar namun ia tidak bisa makan karena sudah tidak memiliki cukup uang untuk membeli pangan dan ia pernah mengurangi jumlah jajan anaknya. Hasil dari pengurangan jumlah jajan anaknya tersebut, ia gunakan sebagai tambahan untuk membeli bahan pangan bagi anggota rumahtangganya. Lain halnya dengan RTKP tahap ekspansi demografis awal yang tingkat ketahanan pangannya termasuk ke dalam kategori "tahan pangan", yaitu Ds (23 tahun). Ds merupakan pengelola pangan di rumahtangganya dan tingkat pendidikannya termasuk ke dalam kategori rendah. Ds sehari-harinya mengurus rumahtangga dan anaknya tertuanya yang masih balita. Suaminya bekerja sebagai montir. Pendapatan yang diperoleh rumahtangga ini adalah Rp 729.400 per bulan. Tingkat ketahanan pangan rumahtangga ini termasuk ke dalam kategori "tahan pangan" karena di rumahtangga ini hanya sedikit bukti ketidaktahanan pangan, yaitu rumahtangga ini sering merasa khawatir pangan untuk keluarganya habis sementara ia tidak mempunyai uang untuk membelinya lagi namun ia tidak pernah sampai mengalami pangan yang dibelinya habis.

\section{Kasus RTKP Tahap Ekspansi Demografis Lanjut}

Salah satu RTKP tahap ekspansi demografis lanjut yang tingkat ketahanan pangannya termasuk ke dalam kategori "lebih tidak tahan pangan" adalah Ne. Ne (38 tahun) adalah pengelola pangan dirumahnya. Ia memiliki enam orang anak, dimana anak tertuanya telah berusia 17 tahun namun tidak melanjutkan sekolah dan saat ini bekerja sebagai penjual plastik di pasar. Kepala keluarga pada rumahtangga ini bekerja sebagai buruh tani. Oleh karena itu, pada rumahtangga ini yang bekerja hanya kepala keluarga dan anak tertuanya. Pendapatan yang diperoleh rumahtangga ini adalah $\mathrm{Rp}$ 844.900 per bulan. Tingkat ketahanan pangan rumahtangga ini termasuk ke dalam kategori "lebih tidak tahan pangan" karena ditemukan beberapa bukti ketidaktahanan pangan, yaitu rumahtangga ini sering merasa khawatir pangan yang ada dirumahnya habis sementara ia sudah tidak mempunyai uang lagi untuk membeli pangan dan tidak mampu mengkonsumsi makanan yang seimbang, mereka cenderung membelanjakan pendapatannya untuk pangan yang mampu mereka peroleh tanpa menghiraukan kandungan zat gizi yang terkandung didalam setiap jenis pangan. Selain itu, agar tetap bisa membeli makanan dalam setahun terakhir ini Ne pernah mengurangi jumlah jajan anak-anaknya. Hal tersebut terpaksa ia lakukan agar ia tetap bisa membeli beras sebagai bahan pangan pokoknya karena yang terpenting adalah anak-anaknya tetap bisa makan dan tidak merasa lapar. Salah satu RTKP tahap ekspansi demografis lanjut yang tingkat ketahanan pangannya termasuk ke dalam kategori "tahan pangan" adalah Ya (41 tahun). Ya merupakan pengelola pangan dirumahtangganya dan tingkat pendidikannya termasuk ke dalam kategori tinggi. Anak tertua Ya berusia 20 tahun, tidak bersekolah dan belum bekerja. Kepala keluarga di rumahtangga ini bekerja sebagai PNS sehingga yang bekerja di rumahtangga ini hanya kepala keluarganya saja. Pendapatan yang diperoleh rumahtangga ini adalah $\mathrm{Rp} 2.445 .950$ per bulan. Tingkat ketahanan pangan rumahtangga ini termasuk ke dalam kategori "tahan pangan" karena terdapat sedikit bukti ketidaktahanan pangan (rumahtangga ini kadang-kadang merasa khawatir pangan yang ada di rumahtangganya habis sementara ia sudah tidak memiliki uang untuk membeli pangannya lagi). Walaupun begitu, di rumahtangga ini selalu mengkonsumsi makanan yang seimbang dan tidak pernah mengurangi jumlah jajan anak dalam setahun terakhir.

\section{PENUTUP}

\section{Kesimpulan}

Tingkat ketahanan pangan rumahtangga Komunitas Jembatan Serong termasuk ke dalam kategori "tahan pangan". Jika dilihat berdasarkan tipe rumahtangga, tingkat ketahanan pangan RTKP berbeda dengan tingkat ketahanan pangan RTKW, dimana tingkat ketahanan pangan RTKP termasuk ke dalam kategori "tahan pangan" sedangkan tingkat ketahanan pangan RTKW termasuk ke dalam kategori "lebih tidak tahan pangan". Perbedaan tingkat ketahanan pangan tersebut tidak menimbulkan ketimpangan ketahanan pangan. Berdasarkan hasil uji statistik Chi Square diketahui bahwa tingkat ketahanan pangan RTKP sama dengan tingkat ketahanan pangan RTKW. Upaya yang dilakukan RTKP "lebih tidak tahan pangan" dalam mengatasi kekurangan pangan dari yang paling sering hingga jarang dilakukan adalah dengan mengutang ke warung, meminjam uang, membeli makanan yang murah, meminta ke saudara, dan bekerja lebih keras. Berbeda dengan RTKP, pada RTKW yang "lebih tidak tahan pangan" upaya yang dilakukan dari yang paling sering hingga jarang dilakukan untuk mengatasi kekurangan pangan adalah dengan meminjam uang, meminta ke saudara, mengutang ke warung, membeli makanan yang murah, bekerja lebih keras, mengurangi makanan jajanan, dan mengurangi frekuensi makan. Strategi yang dilakukan oleh RTKP dan RTKW untuk mengatasi kekurangan pangan berbeda-beda. Pada RTKP, strategi yang sering dilakukan dengan meminjam uang dan mengutang ke warung sedangkan pada RTKW strategi yang sering dilakukan dengan meminjam uang dan meminta ke saudara. Umumnya mereka meminjam uang kepada bank keliling. Strategi lain yang dilakukan oleh RTKP dan RTKW adalah dengan meminjam uang, membeli makanan yang murah, dan mengutang ke warung. Membeli makanan murah, yaitu dengan membeli sembako murah di ketua RT (Rukun Tetangga) yang berasal dari kantor kepala desa.

Hubungan antara tingkat pendidikan pengelola pangan seluruh rumahtangga, RTKP, dan RTKW berhubungan dengan tingkat ketahanan pangan seluruh rumahtangga, RTKP, dan RTKW. Semakin meningkat tingkat pendidikan pengelola pangan maka akan semakin tahan pangan tingkat ketahanan pangannya. Selain itu, ternyata terdapat hubungan antara tingkat pendapatan 
seluruh rumahtangga, RTKP, dan RTKW dengan tingkat ketahanan pangan seluruh rumahtangga, RTKP, dan RTKW. Semakin tinggi tingkat pendapatan maka akan semakin tahan pangan tingkat ketahanan pangannya. Tingkat ketahanan pangan RTKP termasuk ke dalam kategori "tahan pangan". Terdapat kejadian RTKP yang tingkat ketahanan pangannya termasuk ke dalam kategori "lebih tidak tahan pangan" yaitu RTKP lajang. Sedangkan tingkat ketahanan pangan RTKP tanpa anak, RTKP tahap ekspansi demografis awal, dan RTKP tahap ekspansi demografis lanjut termasuk ke dalam kategori "tahan pangan". Berbeda dengan tingkat ketahanan pangan RTKP yang termasuk ke dalam kategori " tahan pangan", tingkat ketahanan pangan RTKW termasuk ke dalam kategori "lebih tidak tahan pangan". Secara keseluruha pada RTKW yang "lebih tidak tahan pangan" ditemukan peristiwa tingkat ketahanan pangan yang termasuk ke dalam kategori "tahan pangan", yaitu RTKW tanpa anak dan RTKW tahap ekspansi demografis awal. Sedangkan tingkat ketahanan pangan RTKW tahap ekspansi demografis lanjut termasuk ke dalam kategori "lebih tidak tahan pangan".

\section{Saran}

Terdapat dua saran dalam penelitian ini berdasarkan penjabaran di atas, yaitu agar setiap rumahtangga memberikan akses yang sama bagi anak laki-laki dan perempuan terhadap pendidikan. Akses yang sama bagi anak laki-laki dan perempuan ini merupakan modal utama untuk menghasilkan kualitas SDM yang baik yang berpendidikan tinggi. Selain itu, diharapkan adanya penghapusan diskriminasi pengupahan terhadap wanita. Baik wanita atau pria yang menjadi kepala rumahtangga memperoleh pendapatan yang sesuai dengan pekerjaan yang dilakukannya dan tidak mempertimbangkan bahwa wanita yang bekerja hanya untuk memberikan tambahan pendapatan sehingga dapat diupah lebih rendah dibandingkan pria.

\section{DAFTAR PUSTAKA}

Alfiasari. 2007. Analisis Ketahanan Pangan Rumahtangga Miskin dan Peranan Modal Sosial (Studi Kasus pada Rumahtangga Miskin di Kecamatan Tanah Sareal dan Kecamatan Bogor Timur, Kota Bogor). Tesis pada Sekolah Pasca Sarjana, Institut Pertanian Bogor. (Tidak diterbitkan). Bogor.

Antang, Emmy Uthanya. 2002. Ketahanan Pangan dan Kebiasaan Makan Rumahtangga pada Masyarakat yang Tinggal di Daerah Sekitar Lahan Gambut, Kalimantan Tengah. Tesis pada Program Pasca Sarjana, Institut Pertanian Bogor. (Tidak diterbitkan). Bogor.

Arumsari, Vini dan Wulandari Dwi Etika Rini. 2007. Peran Wanita Tani dalam Mewujudkan Ketahanan Pangan pada Tingkat Rumahtangga di Kabupaten Sleman, Daerah Istimewa Yogyakarta. Jurnal Ekonomi Pembangunan Vol. 13 No.1, April 2008 Hal: 71-82. (Situs
Universitas Islam Indonesia http://journal.uii.ac.id/index.php/JEP/article/view File/52/150).

Elizabeth, Roosganda. 2007. Peran Ganda Wanita Tani dalam Mencapai Ketahanan Pangan Rumahtangga di Pedesaan. Forum Penelitian Agro Ekonomi. Volume 25 No.2, Desember 2007: 126-135. (Situs Pusat Penelitian Pertanian http://www.puslittan.bogor.net/berkas_PDF/IPT EK/2008/Nomor-1/05-Roosganda.pdf).

Grijns, Mies et al. 1992. "Women at Work: Overview of The Literature on West Java" dalam Gender, Marginalisation, and Rural Industries: Female entrepreneurs, wage workers, and family workers in West Java. Edited Mies Grijns et al. Akatiga Foundation. Bandung.

Indaryanti, Yoyoh. 2003. Analisis Strategi Ketahanan Pangan Komunitas Petani (Studi Kasus di Desa Sidajaya, Kecamatan Cipunagara, Kabupaten Subang, Jawa Barat). Tesis pada Program Pasca Sarjana, Institut Pertanian Bogor. (Tidak diterbitkan). Bogor.

Maisaroh. 2001. Ketahanan Pangan Rumahtangga Petani Desa Sukajadi, Kecamatan Ciomas, Kabupaten Bogor. Skripsi pada Jurusan Gizi Masyarakat dan Sumberdaya Keluarga, Fakultas Pertanian, Institut Pertanian Bogor. (Tidak diterbitkan). Bogor.

Prasodjo, Nuraini W. 1993. Pola Kerja Rumah Tangga Miskin pada Musim Paceklik (Studi Perbandingan pada Komunitas Nelayan dan pertanian Tanaman Pangan di Kecamatan Astanajapura, Kabupaten Cirebon, Jawa Barat). Tesis pada Program asca Sarjana, Institut Pertanian Bogor. (Tidak diterbitkan). Bogor.

Pusat Studi Wanita- IPB bekerjasama dengan Biro Pusat Statistik. 1998. Profil Rumahtangga dan Akses Rumahtangga yang dikepala wanita (WKRT) terhadap Beragam Program Pembangunan. Pusat Studi Wanita, Institut Pertanian Bogor. (Tidak diterbitkan).

Rahayu, Dewi. 2007. Analisis Program Pemberdayaan Masyarakat PT Riau Andalan Pulp And Paper Dalam Kaitannya dengan Upaya Peningkatan Ketahanan Pangan Rumahtangga. Tesis pada Sekolah Pasca Sarjana, Institut Pertanian Bogor. (Tidak diterbitkan). Bogor.

Rindayati, Wiwiek. 2009. Dampak Desentralisasi Fiskal terhadap Kemiskinan dan Ketahanan Pangan di Wilayah Provinsi Jawa Barat. Disertasi pada Sekolah Pasca Sarjana, Institut Pertanian Bogor. (Tidak diterbitkan). Bogor.

Saliem, Handewi Purwanti, Adreng Purwoto, Gatoet Sroe Hardono, Tri Bastuti Purwantini, Yana Supriyatna, Yuni Marisa, dan Waluyo. 2005. Manajemen Ketahanan Pangan Era Otonomi Daerah dan Perum BULOG. Pusat Analisis Sosial Ekonomi dan Kebijakan Pertanian, Badan 
Penelitian dan Pengembangan Pertanian, Departemen Pertanian.

Singarimbun, Masri dan Sofian Effendi. 1989. Metode Penelitian Survai. LP3ES. Jakarta.

Sukiyono, Ketut, Indra Cahyadinata, dan Sriyoto. 2008. Status Wanita dan Ketahanan Pangan Rumahtangga Nelayan dan Petani Padi di Kabupaten Muko-Muko, Provinsi Bengkulu. Jurnal Agro Ekonomi, Volume 26 No.2, Oktober 2008: 191-207. (Situs Departemen Pertanian http://pse.litbang.deptan.go.id/ind/pdffiles/JAE26 - 2d.pdf).

Surbakti, Sudarti. 1990. "Wanita Indonesia dalam Angka" dalam Dinamika Wanita Indonesia Seri 01: Multidimensional. Editor: Toeti Heraty Noerhadi dan Aida Vitayala S. Hubeis. Aksara Buana. Jakarta.

Surbakti, Sudarti. 1991. Strategi Kehidupan Rumahtangga yang dikepala wanita. Editor: Mayling Oey-Gardiner dan Soedarti Surbakti. Biro Pusat Statistik. Jakarta.

Susiana, Sali. 2009. Krisis Ekonomi Global dan Feminisasi Kemiskinan. (Situs Dewan Perwakilan Rakyat (DPR) http://www.dpr.go.id/bukukajian/KrisisEkonomi-Global-dan-Tantangan-dalamPenanggulangan-Kemiskinan---Bab-4-2009.pdf).

Tanziha, Ikeu. 2005. Analisis Peubah Konsumsi Pangan dan Sosial Ekonomi Rumahtangga untuk Menentukan Determinan dan Indikator Kelaparan. Disertasi pada Sekolah Pascasarjana, Institut Pertanian Bogor. Bogor. (Tidak diterbitkan).

Tobing, Farida Lumban. 2010. Gambaran Ketahanan Pangan Keluarga dan Status Gizi Ibu dan Anak Balita di Daerah Rawan Pangan Kecamatan Tanjung Beringin Kabupaten Serdang Bedagai Tahun 2009. Skripsi pada Fakultas Kesehatan Masyarakat, Universitas Sumatera Utara. Medan. (Tidak diterbitkan). (Situs Universitas Sumatera Utara

http://repository.usu.ac.id/bitstream/123456789/1 4731/1/10E00493.pdf). 